\title{
Spatial and Temporal Migration Patterns of Neotropical Migrants in the Southwest Revealed by Stable Isotopes
}
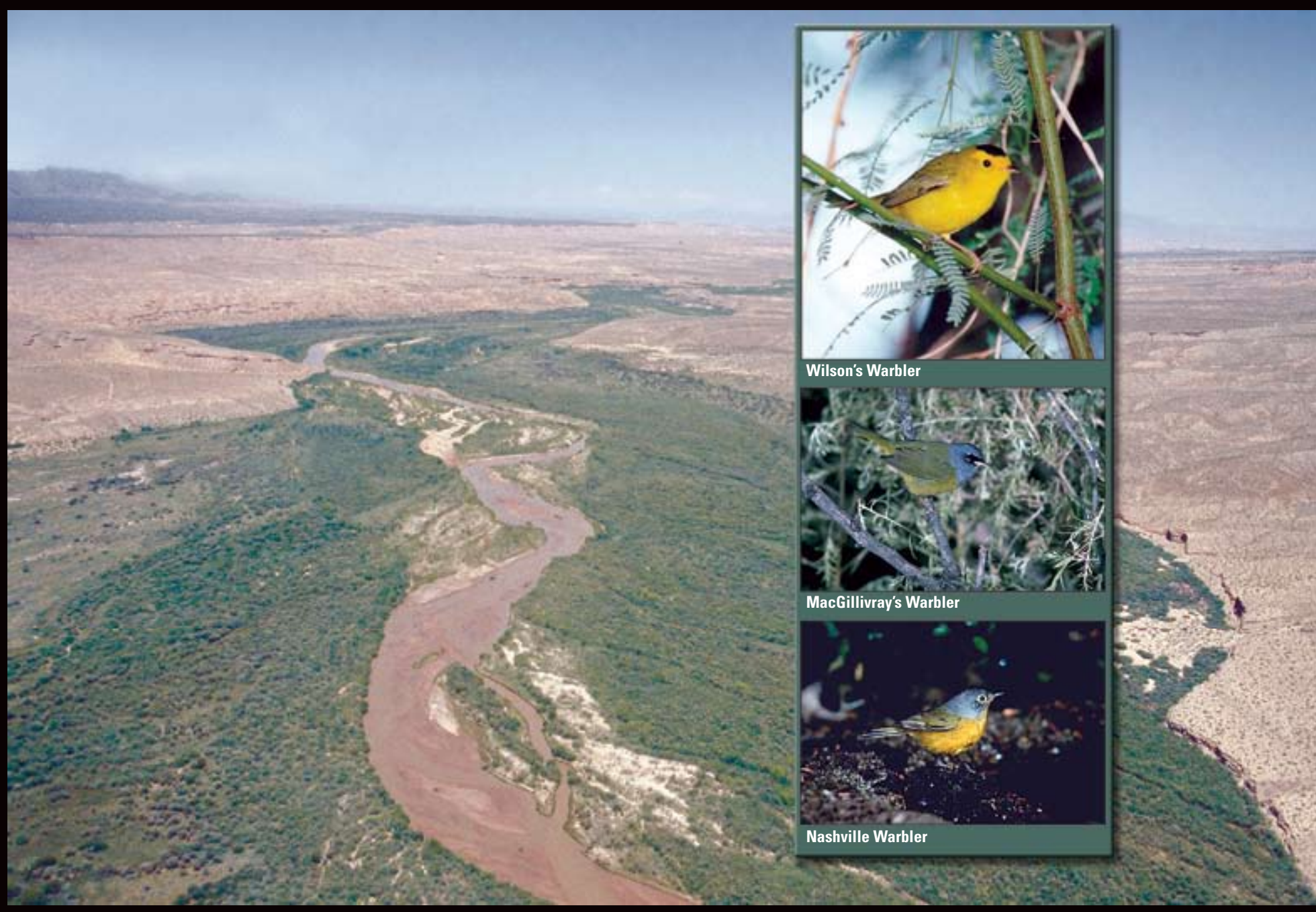

Southwest Biological Science Center

Open-File Report 2005-1298

June 2006

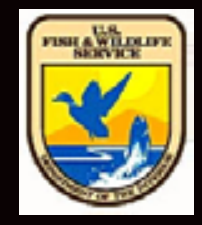

U.S. Department of the Interior

U.S. Geological Survey

National Park Service 



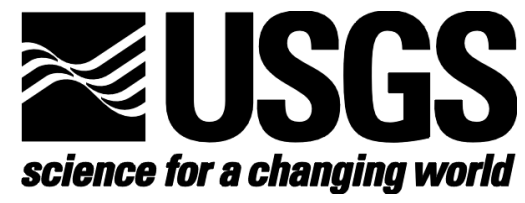

In cooperation with the University of Arizona, School of Natural Resources

\section{Spatial and Temporal Migration Patterns of Neotropical Migrants in the Southwest Revealed by Stable Isotopes}

By Kristina L. Paxton and Charles van Riper III

Open-File Report 2005-1298

June 2006

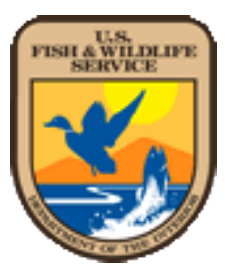

U.S. Department of the Interior

U.S. Geological Survey

USGS Southwest Biological Science Center Sonoran Desert Research Station University of Arizona School of Natural Resources 125 Biological Sciences East Tucson, Arizona 85721 


\section{U.S. Department of the Interior \\ Dirk Kempthorne, Secretary}

\section{U.S. Geological Survey \\ P. Patrick Leahy, Acting Director}

U.S. Geological Survey, Reston, Virginia: 2006

Note: This document contains information of a preliminary nature and was prepared primarily for internal use in the U.S. Geological Survey. This information is NOT intended for use in open literature prior to publication by the investigators named unless permission is obtained in writing from the investigators named and from the Station Leader.

\section{Suggested Citation}

Paxton, K. L., and C. van Riper III. 2006. Spatial and Temporal Migration Patterns of Neotropical Migrants in the Southwest Revealed by Stable Isotopes. USGS Open-File Report 2005-1298.

U.S. Geological Survey, Southwest Biological Science Center, Sonoran Desert Research Station, University of Arizona, Tucson, AZ.

\section{Printed on recycled paper}

Cover photo: Earl Robinson, Brian Small 


\section{Authors}

Kristina L. Paxton

USGS SBSC Colorado Plateau Research Station

P.O. Box 5614

Flagstaff, AZ 86011

Charles van Riper III

USGS SBSC Sonoran Desert Research Station

125 Biological Sciences East Building

The University of Arizona

Tucson, AZ 85721

\section{U.S. Geological SBSC Survey Sonoran Desert Research Station Personnel}

Charles van Riper III, Station Leader

Steve P. Gloss, Ecologist

William L. Halvorson, Research Ecologist

Cecil R. Schwalbe, Ecologist

Michael R. Kunzmann, Ecologist (Emeritus)

Kathryn Thomas, Ecologist

Pamela Nagler, Physical Scientist

Phil Rosen, Ecologist

\section{Program and Expertise Areas of USGS and UA Personnel}

Administration \& Outreach

Kate Leonard

Jennifer Meador

Wendy Parrish

Emily Sherbrooke

Charles van Riper III

Avian Ecology

Claire Crow

Glenn Johnson

Chris O’Brien

Brian Powell

Charles van Riper III

Data Management

Brent Sigafus

Ecology of Amphibians \& Reptiles

Kevin Baker

Cristina Jones

Dave Prival

Phil Rosen

Cecil Schwalbe

Brent Sigafus

Eric Stitt
Fire Management

Dennis Suhre

Cori Dolan

James Feldmann

Bill Halvorson

Invasive Species Research

Patricia Guertin

Jim Malusa

Phil Rosen

Cecil Schwalbe

Brent Sigafus

Dennis Suhre

Kathryn Thomas

Inventory \& Monitoring

Patricia Guertin

Bill Halvorson

Pamela Nagler

Brian Powell

Cecilia Schmidt

Vegetation Mapping \& Ecology

Patricia Guertin

Bill Halvorson

Jim Malusa

Kathryn Thomas

USGS Southwest Biological Science Center http://sbsc.wr.usgs.gov

USGS Southwest Biological Science Center, Sonoran Desert Research Station http://sbsc.wr.usgs.gov/sdrs 


\section{Table of Contents}

Acknowledgements .......................................................................................................................................... vii

Executive Summary ............................................................................................................................... ix

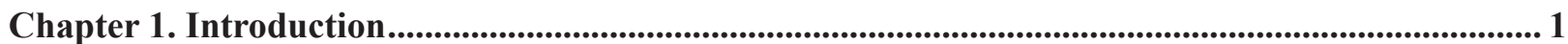

Chapter 2. Spatial and Temporal Migration Patterns of Wilson's Warbler in the Southwest

Revealed by Stable Hydrogen Isotopes ........................................................................................................5 5

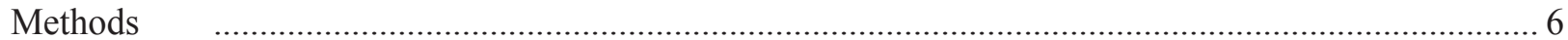

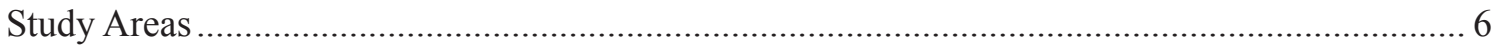

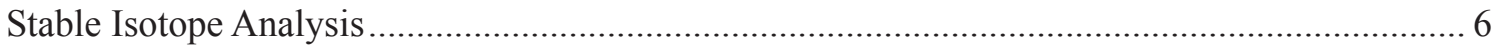

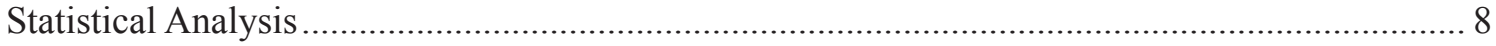

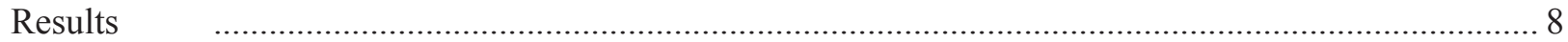

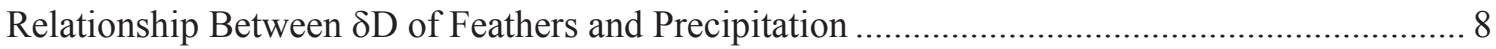

Timing of Migration with Respect to Breeding Location........................................................... 9

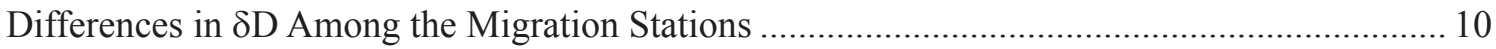

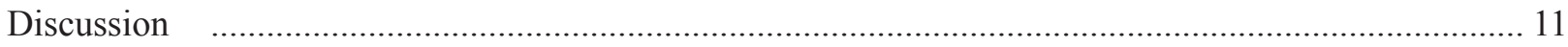

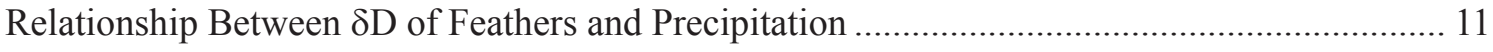

Timing of Migration with Respect to Breeding Location........................................................... 13

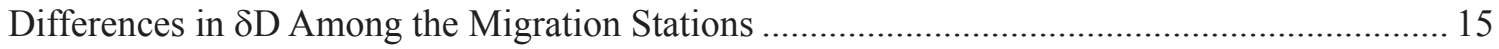

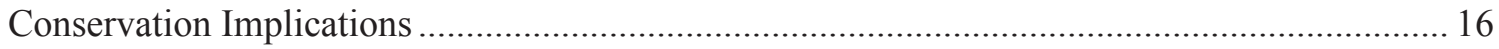

Chapter 3. Migration Patterns Revealed by Stable Isotopes for MacGillivray's and Nashville Warblers in the Southwestern United States................................................................................ 19

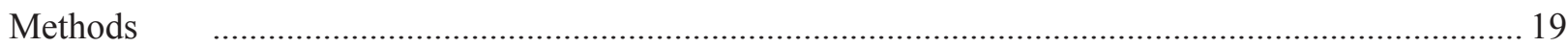

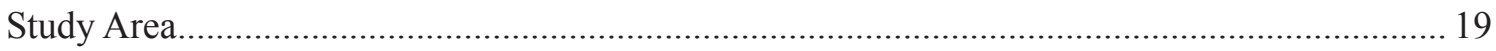

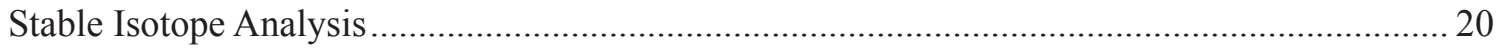

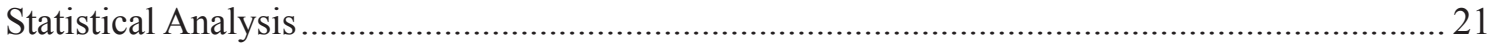

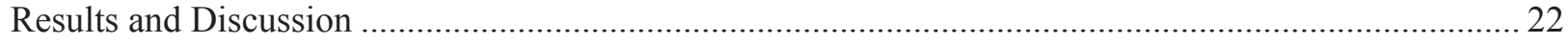

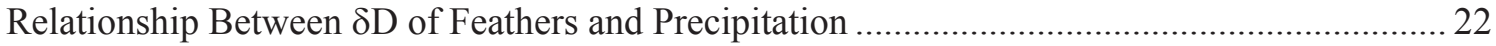

Spatial Distribution of Wintering Populations .......................................................................... 22

Timing of Migration with Respect to Breeding Location.......................................................... 24

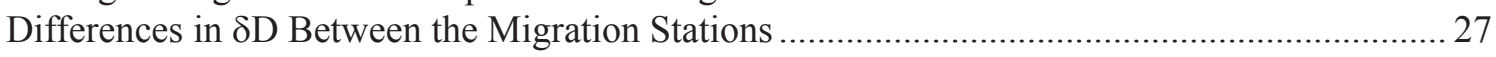

Chapter 4. Conclusions........................................................................................................................................2 29

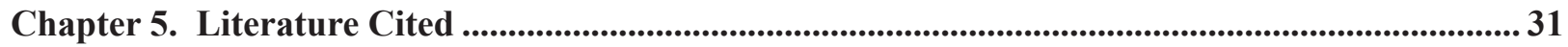

\section{List of Tables}

Table 2.1. Sampling locations and sample size $(n)$ for breeding and migration

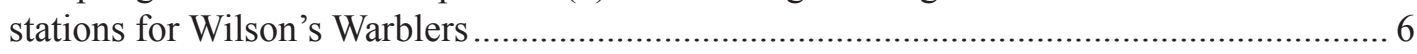

Table 3.1. Sampling locations and sample size $(n)$ for breeding, wintering, and migration stations for MacGillivray's Warblers. 


\section{List of Figures}

Figure 2.1. Location of breeding and migration stations where Wilson's Warblers

feathers were collected.

Figure 2.2. Regression showing the relationship between stable hydrogen isotopes of Wilson's Warbler feathers $\left(\delta \mathrm{D}_{\mathrm{f}}\right)$ collected on their breeding grounds and the growing season precipitation $\left(\delta \mathrm{D}_{\mathrm{p}}\right)$ where warblers were captured......................

Figure 2.3. Regression of $\delta \mathrm{D}$ of migrating Wilson's Warblers, by date, for five sites.......................10

Figure 2.4. Regression of $\delta \mathrm{D}_{\mathrm{x}}$ values of migrating Wilson's Warblers, by date, for different age-sex classes at the Lower Colorado River site for 2003.

Figure 2.5. Timing of migration and $\delta$ D values in 2003 and 2004 at A) Lower Colorado

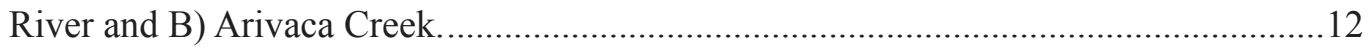

Figure 2.6. Map representing $\delta \mathrm{D}$ values within Wilson's Warblers western

breeding range

Figure 2.7. Demonstration of leapfrog migration for Wilson's Warblers

Figure 3.1. Location of breeding, migration, and wintering stations where MacGillivray's Warblers feathers were collected.

Figure 3.2 Breeding and wintering distribution of Nashville Warblers and migration stations where feathers were collected.

Figure 3.3. Regression showing the relationship between stable hydrogen isotopes of MacGillivray's Warbler feathers $\left(\delta \mathrm{D}_{\mathrm{f}}\right)$ collected on their breeding grounds and the growing season precipitation $\left(\delta \mathrm{D}_{\mathrm{p}}\right)$ where warblers were captured.

Figure 3.4. Regression showing the relationship between stable hydrogen isotopes of MacGillivray's Warbler feathers $(\delta \mathrm{D})$ collected on their wintering grounds and the latitude where warblers were captured....

Figure 3.5. Relationship between the timing of migration and $\delta \mathrm{D}$ values of MacGillivray's Warblers for two sites

Figure 3.6. Map representing $\delta \mathrm{D}$ values found within MacGillivray's Warblers breeding range ......

Figure 3.7. Maps representing $\delta \mathrm{D}$ values found within Nashville Warblers

breeding range 


\section{Acknowledgements}

We would like to thank Tad Theimer and Bruce Hungate for providing guidance with stable isotopes and for their insightful reviews of this work. Also a special thanks to Chris O'Brien, Laura McGrath, Eben Paxton, Stephanie Junker, and Becca Cameron for their help in the field. This project could not have been accomplished without all the help of others in collection of warbler feathers across the southwest. This includes: Sarah Stock at Big Sur Ornithology Lab, Osvel Hinojosa at the Colorado River Delta, Mary Hunnicutt and Ken Voget at Arivaca Creek within Buenos Aires National Wildlife Refuge, Dave Cerasale at San Pedro River, and UCLA Conservation Genetic Resource Center for breeding and wintering feathers.

It was a pleasure to conduct this research on Cibola National Wildlife Refuge. We appreciated the support of Tom Alexander, refuge manager, Bill Seese, assistant manager, and Geary Hund, biologist, in terms of both logistical support such as housing and vehicles and the enthusiasm of the staff for the research that we were conducting at the refuge. We also appreciate the help of Laura McGrath, Suzanne Cardinal, Scott Durst, Bill Bridgeland, Stu Tuttle, Jeff Gagnon, Mark Weissinger, Nate Gwinn, Erika Nowak, Glenn Johnson, Claire Crow, and especially Eben Paxton for his assistance with GIS data layers. Funding sources for this work included support by Denny Fenn and the Southwest Biological Science Center, through the US Geological Survey, and grants from Disney Corporation, through the National Fish and Wildlife Foundation, and Sigma Xi. 


\section{Executive Summary}

We used stable hydrogen isotopes $(\delta \mathrm{D})$ to investigate both temporal and spatial patterns during spring migration for three warbler species, Wilson's Warbler (Wilsonia pusilla), MacGillivray's Warbler (Oporornis tolmiei), and Nashville Warbler (Vermivora ruficapilla), across multiple migration routes in southwest North America. A strong correlation between stable hydrogen isotope values of feathers and the local precipitation at sites where feathers where collected across the breeding range for all three species reaffirmed that stable hydrogen isotopes were a good predictor of breeding locations. For the Wilson's Warbler, we found a significant negative relationship between the date when warblers passed through the sampling station and $\delta \mathrm{D}$ values of their feathers, indicating that warblers who bred the previous season at southern latitudes migrated through the migration stations earlier than did warblers that had previously bred at more northern latitudes. This pattern was consistent across their southwestern migration route ( 5 sites sampled) and was consistent between years. Comparing $\delta \mathrm{D}$ values between migration stations also showed a shift towards more negative $\delta \mathrm{D}$ values from the western to the eastern migration stations sampled in this study, which corresponded to different geographical regions of the Wilson's Warblers' western breeding range. For MacGillivray's Warbler we found the same temporal pattern as Wilson's Warbler, with warblers that bred the previous season at southern latitudes migrating through the migration stations earlier than warblers that had previously bred at more northern latitudes. This pattern was consistent at the Lower Colorado River and Arivaca Creek, the two sites where sample sizes were adequate to test these hypotheses. Comparison of the $\delta \mathrm{D}$ between the two sites indicated that the majority of warblers migrating through these stations were breeding within a geographically limited area of MacGillivray's Warblers' overall breeding range. This is in contrast to the larger range of $\delta \mathrm{D}$ values for Wilson's Warblers at these two sites, which corresponded to a broader area across their breeding range. Feathers were also collected across MacGillivray's Warblers' wintering range, and stable hydrogen isotope analysis indicated a significant positive relationship with wintering latitude. Because the $\delta \mathrm{D}$ value of MacGillivray's Warblers' feathers reflects the $\delta \mathrm{D}$ value of their breeding locations, with more negative values representing more northerly breeding latitudes, this positive relationship between feather $\delta \mathrm{D}$ and wintering latitude indicated that warblers wintering at more southern latitudes bred at more northern latitudes. This supports a leapfrog migration system for MacGillivray's Warblers and is the first documentation of such a pattern. We did not find a temporal pattern to the spring migration of Nashville Warblers. This lack of temporal pattern could be due to the reduced size of the breeding and wintering ranges of Nashville Warblers, both of which could decrease the advantages of a temporal migration pattern. A small population of Nashville Warblers also breeds on the California coast and the sporadic nature of migration for Nashville Warblers in the southwest suggests that in some years more Nashville Warblers may winter along the California coast. The information in this study has increased our understanding of both spatial and temporal patterns of migration for three neotropical migrant birds and has important implications for understanding the ecology and evolution of migrants and factors influencing overall population dynamics. 


\section{Chapter 1. Introduction}

Migration, 'the act of moving from one spatial unit to another' (Baker 1978) occurs in many disparate taxonomic groups including mammals, birds, fish, reptiles, marine invertebrates, and insects and is thus thought to have originated multiple times in animal evolution (Baker 1978). For birds, migration primarily refers to the regular seasonal movement between breeding and non-breeding areas (Lack 1968). Today, it is thought that most birds possess the basic mechanistic repertoire required for migration (Berthold 1999, Helbig 2003, Rappole 2003) as recent studies have shown a strong genetic basis involved in the both the control of bird migration and the mode of inheritance (Berthold 1991, 1992, 1996, Heilbig 1996, Pulido and Berthold 2003). The earliest discussions on migration date back to Aristotle and several references occur in the Bible. Early hypotheses on the evolution of bird migration were focused on geological phenomena such as continental drift and glacial cycles (see Gauthreaux 1982b).

In the 1930s and 40s, the work of R.A. Fisher (1930) and Dobzhansky and Wright (1943) changed the focus of evolutionary discussions within ecology to ideas focused on genes, which also impacted avian ecology and shifted hypotheses on the evolution of bird migration toward ideas focused on concepts of evolutionary fitness. It is recognized today that while events such as glacial cycles certainly influence the geographic distribution of bird migration patterns, these physical events were not the cause of bird migration (Gauthreaux 1982b). Recent hypotheses on the evolution of migration in birds are built primarily upon the basic framework of Lack's (1954) and Salomonsen's (1955) views, which focused on a cost-benefit approach to the evolution of bird migration. These views maintain that the benefits of migration, whether they occur in terms of increased reproduction by breeding in temperate regions, increased survivorship by wintering within tropical regions, or both, must be balanced against the cost of migration (Lack
1954, Blem 1975, Greenberg 1980, Holmes and Sherry 2001, Sillett and Holmes 2002).

Migration represents a critical time period when birds can be at the edge of their physiological limits (Berthold 1975) and may account for the largest amount of mortality in a migrant's annual cycle (Ketterson and Nolan 1982, Sillett and Holmes 2002). This is due to the many challenges that a migrant encounters during the migration time period including: meeting the energetic demands associated with migratory flight (Berthold 1975, Blem 1980, Alerstam and Lindstrom 1990), adjusting to unfamiliar habitats, conflicts between predator avoidance and food acquisition (Metcalfe and Furness 1984, Lindstrom 1990, Moore 1994, Weber et al. 1998), inter- and intra- specific competition for limited resources (Hutto 1985, Moore and Yong 1991, Kelly et al. 2002a), weather conditions (Able 1977, Gauthreaux 1991, Diehl 2003), and the challenges of orientation (Emlen 1975).

Migratory behavior may also vary between seasons and among age and sex classes, resulting in selection for different migratory behaviors between sexes and across age classes (Gauthreaux 1982a, Francis and Cooke 1986, Carpenter et al. 1993, Yong et al. 1998). The higher productivity and survivorship on the breeding and wintering grounds is assumed to be offset by high rates of mortality incurred during the migration period (Lack 1954, Greenberg 1980). However, habitat loss and alterations at one or more periods of the annual cycle could shift the population declines of migratory birds.

In the neartic-neotropical system, avian population declines have been documented in recent decades (Robbins et al. 1989, Askins 1990, Hagan and Johnson 1992, DeSante and George 1994), although the underlying factors causing them are poorly understood. This is partly due to the fact that the majority of research on neotropical migrants primarily focused on their breeding grounds, with minimal research being conducted on the 
wintering grounds, and even less during the migration time period. Determining population limitations from only one period of the annual cycle oversimplifies the issue because events throughout the entire annual cycle are linked. All parts of the annual cycle potentially affect population trends of neotropical migrants (Marra et al. 1998, Gill et al. 2001, Webster et al. 2002), although some periods of the annual cycle may have a bigger impact on populations than others. It is critical that we understand all stages of the annual cycle so that the relative role of each period in contributing to population declines can be determined.

Understanding the ecology, evolution, and conservation of migrating birds is hindered by the difficulty of following individuals and populations throughout the entire year (Webster et al. 2002). In particular, tracking neotropical songbirds over large distances by traditional methods such as banding has produced too few band returns to yield robust information. Likewise, because of the technical limitations of miniaturization, newer methods such as satellite- and radio-telemetry are currently restricted to use on birds over 50 and 11 grams, respectively. The use of genetic markers to distinguish between geographically distinct populations has also shown limited utility at smaller spatial scales, possibly due to the recent expansion of many neotropical migrants and the resulting low levels of population differentiation (Mila et al. 2000, Kimura et al. 2002, Clegg et al. 2003, and Lovette et al. 2004).

In contrast, recent studies have shown that naturally occurring stable isotopes in animal tissues can be used to delineate geographically distinct populations (Chamberlain et al. 1997, Hobson and Wassenaar 1997, Marra et al. 1998). For example, stable hydrogen isotope ratios $(\delta \mathrm{D})$ in the tissues of animals are often correlated with the stable hydrogen isotope ratios of local precipitation (Chamberlain et al. 1997, Hobson and Wassenaar 1997, Kelly et al. 2002b). This relationship is primarily driven by latitude, as precipitation at southern latitudes is more enriched with $\delta \mathrm{D}$ than that at northern latitudes (Ingraham 1998). The additional use of other isotopes such as $\delta^{13} \mathrm{C}, \delta^{15} \mathrm{~N}$, and $\delta^{87} \mathrm{Sr}$ could provide a more precise estimate of geographic origins (Hobson 1999, Chamberlain et al. 1997). In most species of birds, the isotopic signature of feathers reflects the diet of the birds only during the period of growth. Since many species of migrant warblers molt their feathers on or near their breeding grounds before migration (Pyle 1997), the isotopic signature of their feathers should reflect the isotopic signature of that breeding site.

Most studies using stable isotopes have focused on linking breeding and wintering grounds of neotropical migrant songbirds (see review Hobson 2003), but the use of stable isotopes can also be applied to understanding the dynamics of bird migration (Meehan et al. 2001, Wassenaar and Hobson 2001, Kelly et al. 2002b, Smith et al. 2003). This is particularly important as the migration time period has not received attention proportional to the role that it plays in the population dynamics of neotropical migrants (Gauthreaux 1979). Only within the last 10 years has attention been given to the importance of conservation of migrants along migration pathways. Research examining the dynamics of the neartic-neotropical migration systems is still in the early stages compared to our understanding of other periods of the annual cycle and has primarily been focused on migration in the eastern US. In this area, the Atlantic Ocean, Caribbean, and Gulf of Mexico, act as geographic barriers that concentrate birds into distinct migration pathways (Cooke 1915, Rappole 1995). These migratory concentrations, and the remarkable feat of trans-Gulf migration itself, led to intense research within these focal areas that has greatly furthered our understanding of the dynamics of the neartic-neotropical migration in the east (Moore et al. 1992, 1995, 2000).

In contrast, our understanding of migration in the western US remains rudimentary. The lack of geographic barriers in the west suggests that the migration strategies may differ between eastern and western neotropical migrants. It has been hypothesized that in the arid southwest, upland habitat may act as an ecological barrier, concentrating migrants into riparian habitats (Wauer 1977, 
Sprunt 1975), but further study within upland habitat is needed. Emphasis also has been placed on riparian habitats as critical stopover habitat in the west because they comprise less than $1 \%$ of the land while supporting the highest bird abundance and diversity of any other habitat (Johnson et al. 1977, Knopf 1988, Finch and Ruggiero 1993). Stevens et al. (1997) found that 10 times more birds were observed in riparian habitat than the surrounding uplands during spring migration. This habitat is also the most heavily disturbed habitat type in the west and has declined precipitously in the last century due to perturbations such as agriculture conversions (Conine et al. 1978), channelization (McCall and Knox 1979), livestock overgrazing (Knopf and Cannon 1982), and the invasion of the now dominant exotic salt cedar (Hunter et al. 1988). Loss of riparian habitats has had negative effects on birds that breed and winter directly within these habitats, and has the same potential to affect breeding populations of neotropical migrants that use riparian habitat during migration (Rich et al. 2004).

We used stable hydrogen isotopes $(\delta \mathrm{D})$ to investigate the temporal and spatial pattern of migration in three warbler species, Wilson's Warbler (Wilsonia pusilla), MacGillivray's Warbler (Oporornis tolmiei), and Nashville Warbler (Vermivora ruficapilla), in the southwest. The overall goals of this study were to: 1) determine the strength of the correlation between stable hydrogen isotope values of feathers and the local precipitation at sites where feathers were collected across the breeding range; 2) determine the temporal migration pattern exhibited by the three warblers during spring migration at multiple locations across southwestern migration routes; 3 ) compare stable hydrogen isotope values among migration routes to determine if warblers migrate in broad fronts across the southwest or if different breeding populations use different migratory routes; and 4) determine if temporal and spatial migration patterns are consistent among the three species. This report will be divided into two sections, one on the Wilson's Warbler and the second on MacGillivray's and Nashville Warblers. 


\section{Chapter 2. Spatial and Temporal Migration Patterns of Wilson's Warbler in the Southwest Revealed by Stable Hydrogen Isotopes}

Research examining the dynamics of warbler migration in the U.S. has primarily focused on migration systems in the eastern half of the country, while our understanding of migration in the west remains rudimentary. Rapid habitat alterations and loss of critical stopover habitat in the southwestern U.S. over the last century compel us to understand the temporal and spatial distribution of neotropical migrants like Wilson's Warbler (Wilsonia pusilla) across southwestern migration routes. We also need to understand how habitat alterations could potentially affect different breeding populations. Traditional methods such as banding have yielded little data to answer these questions, but recent studies have shown that naturally occurring stable isotopes in animal tissues can be used to delineate geographically distinct populations (Chamberlain et al. 1997, Hobson and Wassenaar 1997, Marra et al. 1998).

Using stable hydrogen isotopes, we examined migration patterns of Wilson's Warblers during spring migration at multiple migration stations spanning their southwestern migration route. Wilson's Warblers molt their feathers once on the breeding grounds prior to migration (Pyle 1997), and because the $\delta \mathrm{D}$ of feathers reflects the diet of the birds only during the period of growth, the isotope value of a Wilson's Warbler feather collected during migration represents the isotopic signature of its breeding location.

The two western subspecies of Wilson's Warblers (Wilsonia pusilla pileolata and Wilsonia pusilla chryseola) are abundant migrants throughout the southwestern U.S., migrating north to breeding locations across western North America that represent a wide range of $\delta \mathrm{D}$ values, from coastal regions of California to Alaska and to high elevations within the intermountain west extending northward into western Canadian provinces (Ammon and Gilbert 1999). Based on $\delta \mathrm{D}$ values, Wilson's Warblers exhibit leapfrog migration in which the latitudinal sequence of warblers on the breeding grounds is opposite that of the wintering grounds, i.e., the northernmost breeding warblers winter at the southern edge of the Wilson's Warblers' winter range (Kelly et al. 2002b, Clegg et al. 2003). During autumn migration at one site in New Mexico, Kelly et al. (2002b) found that the northernmost breeders passed through their site first, ahead of more southern-breeding birds, but the same temporal pattern was not found during spring migration. This study expands on this earlier work by examining the temporal pattern of spring migration for Wilson's Warblers in multiple years and at multiple sites. In addition, we test whether Wilson's Warblers exhibiting differing $\delta \mathrm{D}$ values, use different migration routes by comparing $\delta \mathrm{D}$ values of warblers passing through multiple migration stations spanning their southwestern migration route. This information increases our understanding of how the breeding and migration cycle of Wilson's Warblers are connected and could suggest why population declines are observed in some western populations and not in others (DeSante and George 1994, Sauer et al. 2003).

This study is the first large-scale study using stable isotopes to explore dynamics of bird migration at multiple locations across a species' migratory route and to examine variability between two years. Our goals were to: 1) determine the strength of the correlation between stable hydrogen isotope values of Wilson's Warbler feathers and the local precipitation at sites where feathers were collected across the breeding range; 2) determine the temporal migration pattern exhibited by Wilson's Warblers during spring migration at multiple locations across southwestern migration routes; 3) compare stable hydrogen isotope values among migration routes to determine if Wilson's Warblers migrate in broad fronts across the southwest or whether different breeding populations use different migratory routes; and 4) determine if temporal and spatial migration patterns are consistent between years. 


\section{Methods}

\section{Study Areas}

To determine the relationship between $\delta \mathrm{D}$ values of Wilson's Warbler feathers collected on the breeding grounds and local precipitation where they were captured (feathers were provided by the UCLA Conservation Genetics Resource Center), $\delta \mathrm{D}$ values were determined from a single rectrix collected from 63 Wilson's Warblers across their western breeding grounds between 1996 and 2002 (Table 2.1, Fig 2.1). All feathers were from adults, with males and females sampled. To ensure that these feathers were from breeding individuals, only warblers captured between 15 June and 15 August were included. A GIS-derived map of $\delta \mathrm{D}$ values for growing season precipitation across North America (Meehan et al. 2004) was used to obtain $\delta \mathrm{D}$ values of local precipitation where breeding warblers were sampled. In addition, we examined the relationship between $\delta \mathrm{D}$ values of the feathers collected on the breeding grounds and collection site latitude, distance from coast, and elevation, all of which affect $\delta \mathrm{D}$ values in precipitation in North America (Ingraham 1998).
We captured Wilson's Warblers during spring migration between 15 March and 1 June 2003 at four sites: Colorado River Delta in Baja California, Mexico; Lower Colorado River at Cibola National Wildlife Refuge (NWR) in southwestern Arizona; Arivaca Creek at Buenos Aires NWR in southeastern Arizona; and San Pedro River at San Pedro Riparian National Conservation Area in southwestern Arizona. In 2004, warblers were again captured during the same time period at the Lower Colorado River site and Arivaca Creek site and at an additional site, Big Sur, California (Table 2.1, Fig. 2.1) Warblers were caught by passive mistnetting, banded, standard morphological measurements taken, and an outer rectrix from each side of the tail pulled for stable isotope analysis. Feathers were stored in labeled sealed envelopes until analyzed.

\section{Stable Isotope Analysis}

Feathers were washed in detergent and thoroughly rinsed to remove oil, dirt, and residual detergent (Chamberlain et al. 1997, Kelly et al. 2002), and then air-dried at room temperature. Feather material from the distal end $(0.33-0.37 \mathrm{mg})$

Table 2.1 Sampling locations and sample size $(n)$ for breeding and migration stations for Wilson's Warblers. Average stable hydrogen isotope values $(\delta D)$ indicated for each site.

\begin{tabular}{llcc}
\hline Sampling Site & Latitude-Longitude & $n$ & $\delta \mathrm{D}( \pm \mathrm{SD})$ \\
\hline Breeding & $57^{\circ} 12^{\prime} \mathrm{N} 157^{\circ} 19^{\prime} \mathrm{W}$ & 4 & $-111.23(9.14)$ \\
A. Mother Goose Lake, AK & $63^{\circ} 25^{\prime} \mathrm{N} 150^{\circ} 26^{\prime} \mathrm{W}$ & 8 & $-151.7(8.38)$ \\
B. Denali National Park, AK & $51^{\circ} 39^{\prime} \mathrm{N} 121^{\circ} 17^{\prime} \mathrm{W}$ & 6 & $-148.78(5.99)$ \\
C. 100 MileHouse, British Columbia & $46^{\circ} 56^{\prime} \mathrm{N} 121^{\circ} 04^{\prime} \mathrm{W}$ & 10 & $-115.25(9.4)$ \\
D. Wenatchee National Forest, WA & $44^{\circ} 15^{\prime} \mathrm{N} 122^{\circ} 00^{\prime} \mathrm{W}$ & 14 & $-84.51(5.57)$ \\
E. Willamette National Forest, OR & $39^{\circ} 37^{\prime} \mathrm{N} 120^{\circ} 31^{\prime} \mathrm{W}$ & 5 & $-87.46(4.8)$ \\
F. Tahoe National Forest, CA & $48^{\circ} 23^{\prime} \mathrm{N} 114^{\circ} 02^{\prime} \mathrm{W}$ & 5 & $-123.73(3.28)$ \\
G. Flathead National Forest, MT & $39^{\circ} 02^{\prime} \mathrm{N} 107^{\circ} 57^{\prime} \mathrm{W}$ & 6 & $-103.79(3.61)$ \\
H. Grand Mesa,CO & & & \\
& & & \\
Migration & $36^{\circ} 16^{\prime} \mathrm{N} 121^{\circ} 49^{\prime} \mathrm{W}$ & 112 & $-62.88(15.86)$ \\
I. Big Sur, California & $32^{\circ} 18^{\prime} \mathrm{N} 115^{\circ} 20^{\prime} \mathrm{W}$ & 99 & $-77.7(24.73)$ \\
J. Colorado River Delta, Baja California, MX & $33^{\circ} 18^{\prime} \mathrm{N} 114^{\circ} 41^{\prime} \mathrm{W}$ & 185 & $-95.88(24.7)$ \\
K. Lower Colorado River, AZ & $31^{\circ} 33^{\prime} \mathrm{N} 111^{\circ} 33^{\prime} \mathrm{W}$ & 77 & $-92.73(22.38)$ \\
L. Arivaca Creek, AZ & $31^{\circ} 34^{\prime} \mathrm{N} 110^{\circ} 07^{\prime} \mathrm{W}$ & 113 & $-102.68(24.47)$ \\
M. San Pedro River, AZ & & &
\end{tabular}




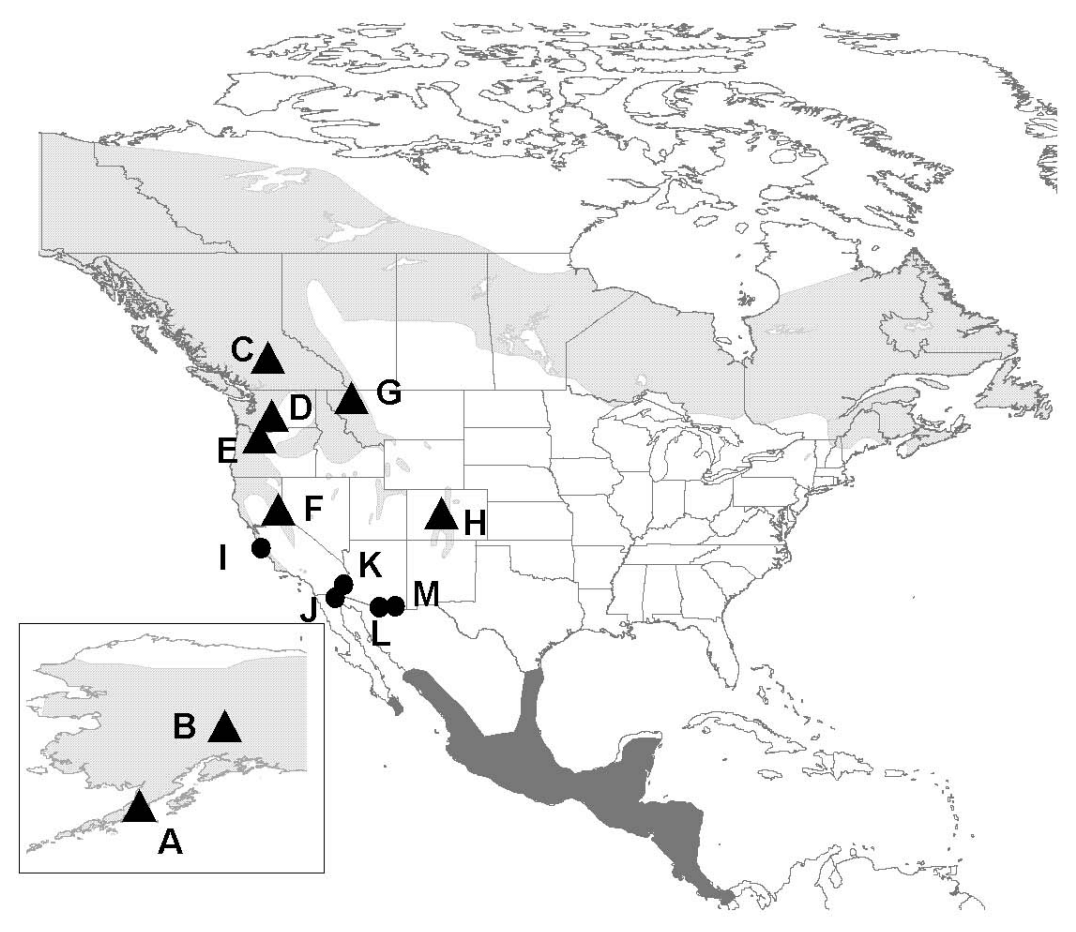

Figure 2.1. Location of breeding and migration stations where Wilson's Warblers feathers were collected. (See Table 2.1 for site information.) Light gray and dark gray shaded regions indicate Wilson's Warblers breeding and wintering range respectively. Triangles represent sites where feathers were collected on breeding ground and circles represent migration stations.

was removed and wrapped in a silver capsule for isotopic analysis. Due to the problem of uncontrolled isotopic exchange between approximately $13 \%$ of non-carbon-bound hydrogen in feathers and ambient water vapor (Chamberlain et al. 1997), we used a comparative equilibrium approach with calibrated keratin standards to correct for this effect. As a result, values presented in this paper are non-exchangeable feather hydrogen only. Details of this method and standards used are described in Wassenaar and Hobson (2003). Unlike past methods to control for non-exchangeable feather hydrogen, this method allows for comparisons of $\delta \mathrm{D}$ values between years and among laboratories.

All stable isotope analysis was conducted at the Colorado Plateau Stable Isotope Laboratory located at Northern Arizona University. Hydrogen stable isotope ratios for feathers and keratin standards were determined on $\mathrm{H}_{2}$ gases, produced by high temperature flash pyrolysis of feathers using a Thermo Finnigan High TemperatureConversion Elemental Analyzer $\left(1400^{\circ} \mathrm{C}\right)$ interfaced through an open split (Finnigan Conflo II) with a continuous flow isotope ratio mass spectrometer (Finnigan Delta Plus XL). The stable hydrogen isotope ratios $\left({ }^{2} \mathrm{H} /{ }^{1} \mathrm{H}\right)$ are all presented in delta $(\delta)$ notation:

$\delta \mathrm{D}_{\text {sample }}=\left[\left(\mathrm{R}_{\text {sample }} / \mathrm{R}_{\text {standard }}\right)-1\right] \times 1000$

Results for $\delta \mathrm{D}$ are expressed in per mil notation (\%o) relative to a standard, VSMOW. Repeat analyses of internal hydrogen isotope standards yielded an external repeatability of $\pm 2.3 \%$. Duplicates of the same feather sample $(n=23)$, comparison of values from two rectrices from the same warbler $(\mathrm{n}=23)$, and from a rectrix and a 
secondary feather from the same warbler $(n=40)$ had an average standard deviation of $\pm 2.3 \%$, \pm $1.5 \%$, and $\pm 5.8 \%$ respectively.

\section{Statistical Analysis}

We utilized linear regression to examine the relationship between timing of migration and putative breeding location based on $\delta \mathrm{D}$. To determine whether the same pattern was exhibited in 2003 and 2004 at the Lower Colorado River and Arivaca Creek sites, an ANCOVA was used. The location of sampling stations across a large portion of the Wilson's Warblers' southwestern migration route enabled us to examine whether birds with different $\delta \mathrm{D}$ values, and therefore from different breeding grounds, migrated in broad fronts across the southwest, or if they were confined to a specific migration route. To address this question, we first examined differences in the mean $\delta \mathrm{D}$ values for each sampling station using an ANOVA. Second, to examine how potential differences in the $\delta \mathrm{D}$ ranges among the sampling stations related to breeding locations within Wilson's Warblers' breeding range, we used the GIS map of $\delta \mathrm{D}$ values of precipitation across North America
(Meehan et al. 2004) and clipped out the Wilson's Warblers' breeding range so that we could query $\delta \mathrm{D}$ values only within this geographical area. To determine where Wilson's Warblers, captured at our migration stations $\left(\delta \mathrm{D}_{\mathrm{x}}\right)$, occurred within their breeding range, we used the regression equation that expressed the relationship between $\delta \mathrm{D}$ of feathers $\left(\delta \mathrm{D}_{\mathrm{f}}\right)$ and $\delta \mathrm{D}$ of local precipitation $\left(\delta \mathrm{D}_{\mathrm{p}}\right)$. To be conservative and account for error within the regression model and the deuterium map, we queried $\delta \mathrm{D}$ values from the GIS map within $20 \%$ ranges. All GIS analyses were done with ArcGIS 8.2. All statistical analyses were conducted with SPSS v12.0, 2003, and significance for statistical tests was assessed at $\mathrm{p} \leq 0.05$.

\section{Results}

Relationship Between $\delta D$ of Feathers and Precipitation

We found a significant positive relationship between the $\delta \mathrm{D}_{\mathrm{f}}$ of Wilson's Warblers' feathers and $\delta \mathrm{D}_{\mathrm{p}}$ where warblers were captured $\left(\mathrm{F}_{1,61}=\right.$ 610.78, $\mathrm{P}<0.001, \mathrm{R}^{2}=0.91$ ) (Fig. 2.2), consistent with data indicating Wilson's Warblers molt their feathers on or near their breeding grounds. The relationship between $\delta \mathrm{D}$ of Wilson's Warblers'

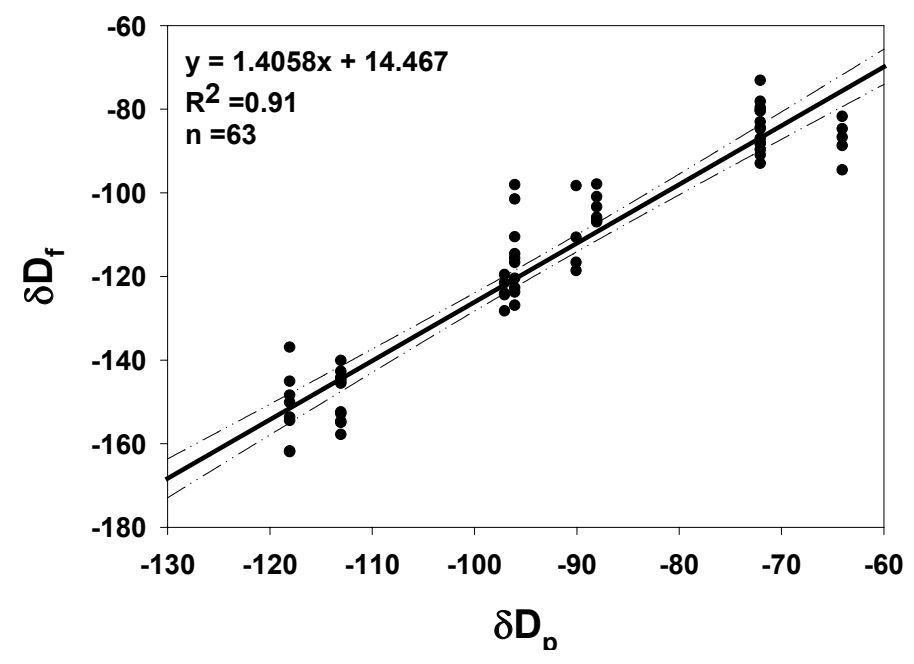

Figure 2.2. Regression showing the relationship between stable hydrogen isotopes of Wilson's Warbler feathers $\left(\delta D_{f}\right)$ collected on their breeding grounds and the growing season precipitation $\left(\delta D_{p}\right)$ where warblers were captured. Dashed lines represent the $95 \%$ confidence intervals. 
feathers and parameters such as latitude, distance from coast, and elevation where warbler feathers were collected was best explained by a regression model that incorporated both latitude and elevation $\left(\mathrm{F}_{2,60}=161.38, \mathrm{P}<0.001, \mathrm{R}^{2}=0.84\right)$. This model indicated a strong negative relationship between $\delta \mathrm{D}$ of Wilson's Warblers' feathers and latitude of collection $(\mathrm{t}=-17.38, \mathrm{P}<0.001, \mathrm{~B}=-3.49 / 1000$ $\mathrm{m} \pm 0.2)$ and elevation $(\mathrm{t}=-11.12, \mathrm{P}<0.001, \mathrm{~B}=$ $-0.018 / 1000 \mathrm{~m} \pm 0.002)$. These data support past research (Chamberlain et al. 1997, Hobson et al. 1997, Kelly et al. 2002, Rubenstein et al. 2002) that demonstrated a strong relationship between $\delta \mathrm{D}$ of bird feathers and latitude, but also indicate that, in mountainous western North America, elevation must also be incorporated into $\delta \mathrm{D}$ models.

\section{Timing of Migration with Respect to Breeding Location}

We found a significant, negative relationship between the date when warblers passed through the sampling station and $\boldsymbol{\delta D}$ values of their feathers (Fig 2.3). This indicates that warblers who bred the previous season at southern latitudes migrated through the migration stations earlier than did warblers that had previously bred at more northern latitudes. Four out of the five migration stations showed a significant relationship: Big Sur $\left(\mathrm{F}_{1,110}=\right.$ 104.37, $\mathrm{P}<0.001, \mathrm{R}^{2}=0.49$ ), Colorado River Delta $\left(\mathrm{F}_{1,97}=48.03, \mathrm{P}<0.001, \mathrm{R}^{2}=0.33\right)$, Lower Colorado River $\left(\mathrm{F}_{1,183}=128.47, \mathrm{P}<0.001, \mathrm{R}^{2}=0.41\right)$, and Arivaca Creek $\left(\mathrm{F}_{1,75}=15.95, \mathrm{P}<0.001, \mathrm{R}^{2}=0.18\right)$. While the regression at the San Pedro River was only marginally significant $\left(\mathrm{F}_{1,101}=3.31, \mathrm{P}=0.07\right)$, a similar trend was evident.

Differential migration strategies between

age and sex classes of Wilson's Warblers contributed variation to the overall relationship between the date when warblers passed through the sampling station and $\delta \mathrm{D}$ values of feathers. When examining the pattern individually for males and females, both sexes showed a significant negative relationship between the date when warblers passed through the sampling station and $\delta \mathrm{D}$ values of their feathers at all sites except Arivaca Creek where the sample size for females was small $(\mathrm{n}=14)$ (Big Sur: $\mathrm{M}: \mathrm{F}_{1,69}=30.94, \mathrm{P}<0.001, \mathrm{R}^{2}=$ $0.31, \mathrm{~F}: \mathrm{F}_{1,34}=50.84, \mathrm{P}<0.001, \mathrm{R}^{2}=0.60$, Colorado River Delta: $\mathrm{M}: \mathrm{F}_{1,78}=32.78, \mathrm{P}<0.001, \mathrm{R}^{2}=$
0.30 , F: $\mathrm{F}_{1,17}=22.75, \mathrm{P}<0.001, \mathrm{R}^{2}=0.57$, Lower Colorado River: $\mathrm{M}: \mathrm{F}_{1,122}=125.55, \mathrm{P}<0.001, \mathrm{R}^{2}=$ $0.51, \mathrm{~F}: \mathrm{F}_{1,56}=17.56, \mathrm{P}<0.001, \mathrm{R}^{2}=0.24$, Arivaca Creek: $\mathrm{M}: \mathrm{F}_{1,56}=12.54, \mathrm{P}<0.001, \mathrm{R}^{2}=0.18, \mathrm{~F}$ : $\mathrm{F}_{1,13}=0.078, \mathrm{P}=0.79$, and San Pedro: $\mathrm{M}: \mathrm{F}_{1,52}=$ 3.41, $\left.\mathrm{P}=0.07, \mathrm{~F}: \mathrm{F}_{1,47}=1.159, \mathrm{P}=0.29\right)$. Males, however, consistently had an earlier mean arrival date than females at all sites. Comparison of the regressions between males and females at each individual site indicated that the slopes of the lines were not significantly different at all sites; at the Lower Colorado River site, which had the largest sample size, the intercepts were significantly different (ANCOVA: $\mathrm{F}_{1,183}=6.825, \mathrm{P}=0.01$ ). The same trend was shown at all the other sites with the regression line of the females shifted above and to the right of the male regression line, corresponding to the shift in timing of arrival between the sexes. We also examined the relationship between date of passage and the $\delta \mathrm{D}$ values for different age and sex classes at the Lower Colorado River where there was a sufficient sample size for each class (Fig. 2.4). We found a significant pattern for both after-second-year males $\left(\mathrm{F}_{1,86}=104.91\right.$, $\left.\mathrm{P}<0.001, \mathrm{R}^{2}=0.55\right)$ and after-second-year females $\left(\mathrm{F}_{1,24}=11.44, \mathrm{P}=0.002, \mathrm{R}^{2}=0.32\right)$ which were captured throughout most of the migration season. Second-year males and second-year females had a truncated migration that only occurred toward the end of the migration season, but still covered a large range of $\delta \mathrm{D}$ values. This type of migration pattern may have contributed to the non-significant pattern for second-year males $\left(\mathrm{F}_{1,31}=2.78, \mathrm{P}=0.11\right)$ and second-year females $\left(\mathrm{F}_{1,26}=1.50, \mathrm{P}=0.23\right)$.

The same temporal pattern that occurred during the 2003 spring migration season was found in 2004 at the Lower Colorado River $\left(\mathrm{F}_{1,170}\right.$ $\left.=276.71, \mathrm{P}<0.001, \mathrm{R}^{2}=0.62\right)$ and Arivaca Creek $\left(\mathrm{F}_{1,37}=35.48, \mathrm{P}<0.001, \mathrm{R}^{2}=0.49\right)$ sites (Fig. $2.5)$. Comparison of the relationship between $\delta$ D values and date of capture between 2003 and 2004 at both sites revealed that the temporal pattern was not significantly different between the years for either site (ANCOVA: Lower Colorado River: $\mathrm{F}_{1,353}=0.40, \mathrm{P}=0.53$, Arivaca Creek: $\mathrm{F}_{1,112}$ $=0.476, \mathrm{P}=0.49$ ). Thus the pattern of migration for populations of breeding Wilson's Warblers sampled at the Lower Colorado River and Arivaca Creek sites was consistent from year to year. 

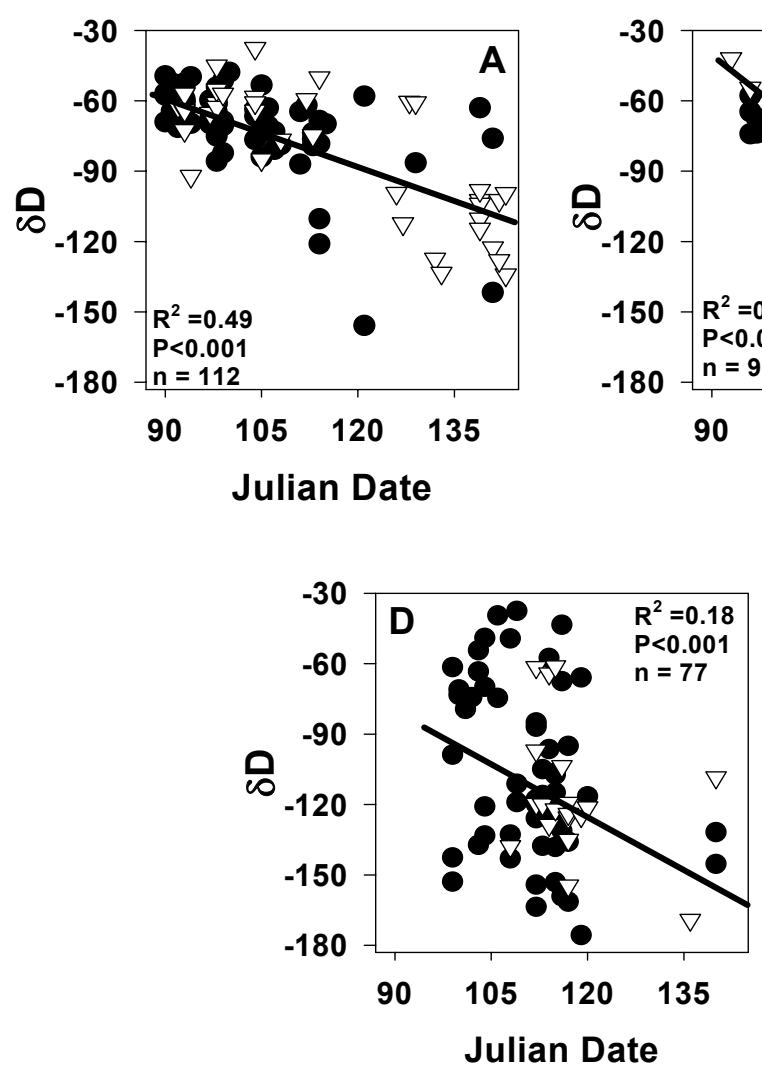
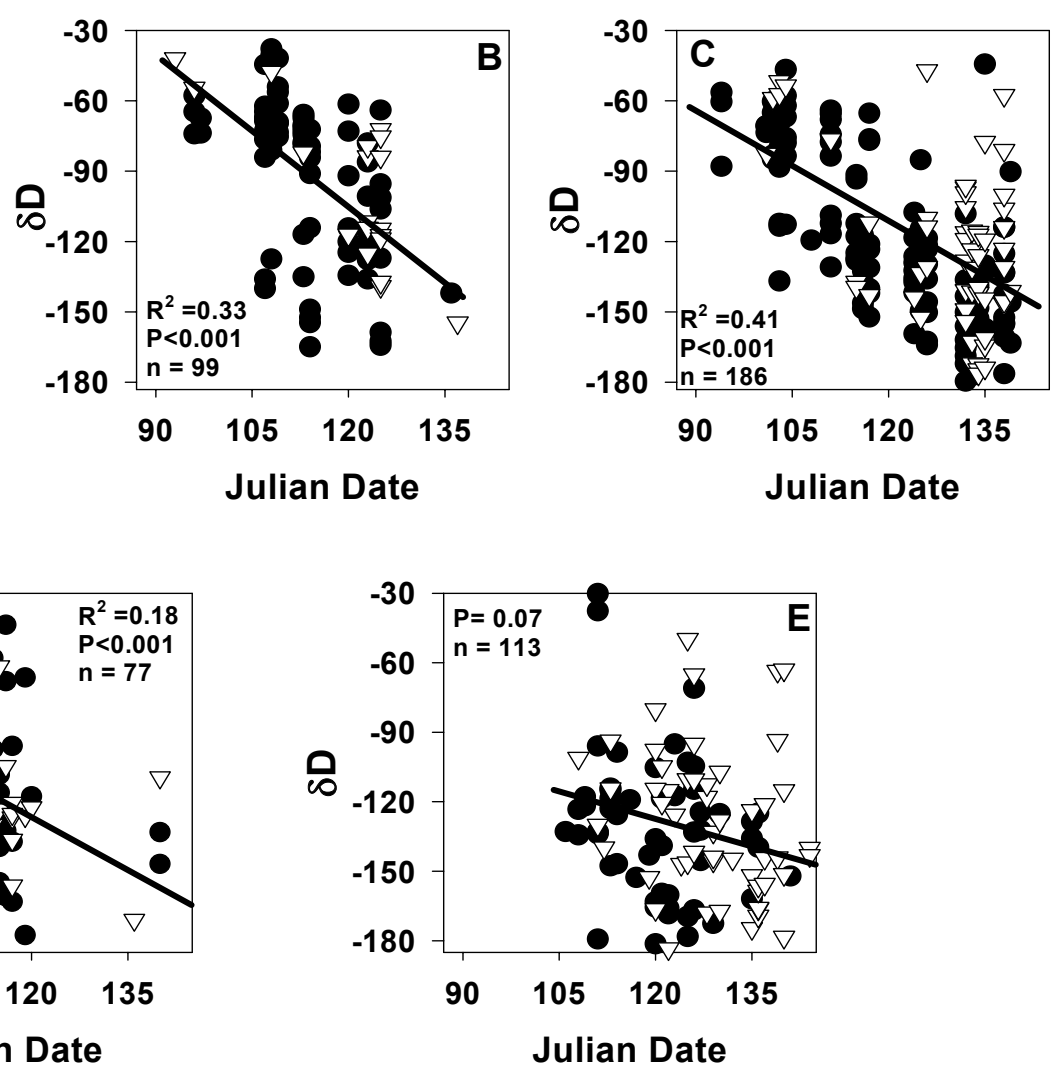

Figure 2.3. Regression of $\delta D$ of migrating Wilson's Warblers, by date, for five sites. A negative relationship is shown between the timing of migration and $\delta \mathrm{D}$ of migrating warblers with warblers arriving earlier in the season having more enriched values of $\delta \mathrm{D}$. This pattern was the same for both males (black circles) and females (white triangles). Migration sites are A) Big Sur, B) Colorado River Delta, C) Lower Colorado River, D) Arivaca Creek, E) San Pedro River. All sites were sampled during the same time period, 15 March to 1 June. $\delta D$ values that are more negative or depleted represent more northern breeding locations while more positive or enriched $\delta \mathrm{D}$ values represent more southern breeding locations.

\section{Differences in $\delta D$ Among the Migration Stations}

Differences in mean $\delta D_{x}$ values among the migration stations showed a shift towards more negative $\delta \mathrm{D}_{\mathrm{x}}$ values from the western to the eastern migration stations sampled in this study (Fig 2.6). There was a significant difference in the mean $\delta D_{x}$ values among all sites except the Lower Colorado River and Arivaca Creek (Tukey's post hoc-test, $\left.\mathrm{F}_{4,565}=55.61, \mathrm{P}<0.001\right)$. The range of $\delta \mathrm{D}_{\mathrm{x}}$ values was also consistent from one year to the next when tested at two sites (Lower Colorado River: $\mathrm{t}=$ 2.069, $\mathrm{p}=0.30$, Arivaca Creek $\mathrm{t}=-1.414, \mathrm{p}=0.16$ ).
We found that the geographic distribution of $\delta \mathrm{D}$ values within Wilson's Warblers' breeding range forms distinct regions within $20 \%$ ranges (Figure 2.6). Within Wilson's Warblers' western breeding range the $\delta \mathrm{D}$ values between -41 to -60 $\%$ occur only along the California Coast, while values between -61 to $-80 \%$ correspond with the Pacific Slope Region and a small portion of the range in the mountains of New Mexico and Colorado. The Sierra Nevada Mountains and Intermountain West Region contain $\delta \mathrm{D}$ values between -81 to $-100 \%$, while $\delta \mathrm{D}$ values between -101 to $-140 \%$ occur within the western Canadian 


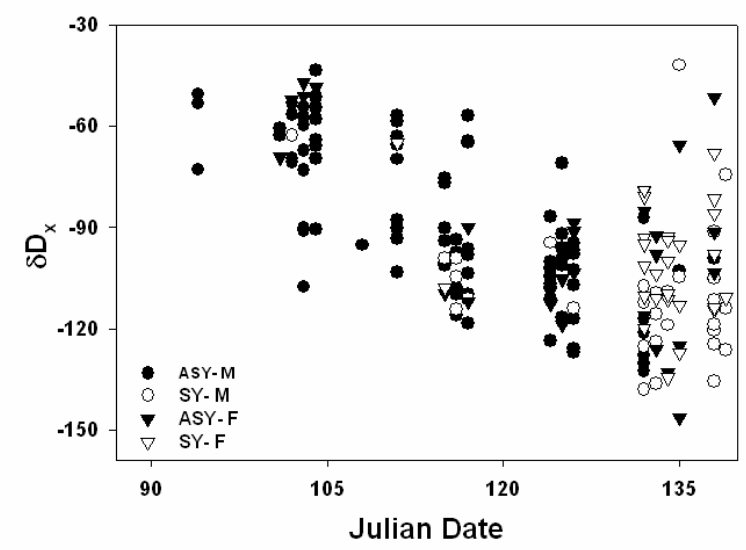

Figure 2.4. Regression of $\delta D_{x}$ values of migrating Wilson's Warblers, by date, for different age-sex classes at the Lower Colorado River site for 2003. After-second-year males (solid black circles) and after-second-year females (solid black triangle) share a similar pattern, while second-year males (open white circle) and second-year females (open white triangle) do not, likely due to the truncated migration occurring at the end of the migration season.

provinces and Alaska, and $\delta \mathrm{D}$ values between 141 to $-160 \%$ are found only within the Yukon Territory of Canada.

The range of $\delta \mathrm{D}_{\mathrm{x}}$ values at each of the migration stations corresponded to $\delta \mathrm{D}$ values in different geographical regions of the Wilson's Warblers' western breeding range. At the most western migration station (Big Sur) the range of $\delta \mathrm{D}_{\mathrm{x}}$ values represented a very limited geographic area within Wilson's Warblers' breeding range, with over $80 \%$ of migrating warblers with $\delta \mathrm{D}_{\mathrm{x}}$ values consistent with those along the California coast and Pacific slope region (Figure 2.6a).

Wilson's Warblers migrating through the Colorado River Delta represented a larger breadth of $\delta \mathrm{D}_{\mathrm{x}}$ values, with $55 \%$ of the Wilson's Warblers migrating through this station with $\delta \mathrm{D}_{\mathrm{x}}$ values consistent with those along the California coast and Pacific slope region and approximately $23 \%$ of the warblers with values like that of the intermountain west (Figure 2.6b). The Lower Colorado River and Arivaca Creek represented intermediate sites, with warblers migrating through these stations having values corresponding to breeding locations across the Wilson's Warblers' breeding range. Most $(80 \%)$ of $\delta D_{x}$ values at these migration stations were consistent with those along the Pacific slope region, intermountain west, and lower regions of the western Canadian Provinces (Figure 2.6c). In contrast, at the San Pedro River, the eastern-most sampling site, $30 \%$ of the Wilson's Warblers had values expected in the intermountain west, while over $60 \%$ had values consistent with those in western Canadian provinces and Alaska (Figure 2.6d). While warblers migrating through this migration station represented a broad geographic area within Wilson's Warblers' breeding range, the majority of $\delta \mathrm{D}_{\mathrm{x}}$ values were restricted to highly depleted values.

\section{Discussion}

Relationship Between $\delta D$ of Feathers and Precipitation

The strong relationship between $\delta \mathrm{D}$ of Wilson's Warblers' feathers collected on the breeding grounds and that of the local precipitation at the sites where they were collected provides further evidence that Wilson's Warblers molt their feathers on or near their breeding grounds and supports past research showing the utility of using stable hydrogen isotopes to delineate breeding origins of certain neotropical migrant birds (Chamberlain et al. 1997, Hobson et al. 1997). These data also 

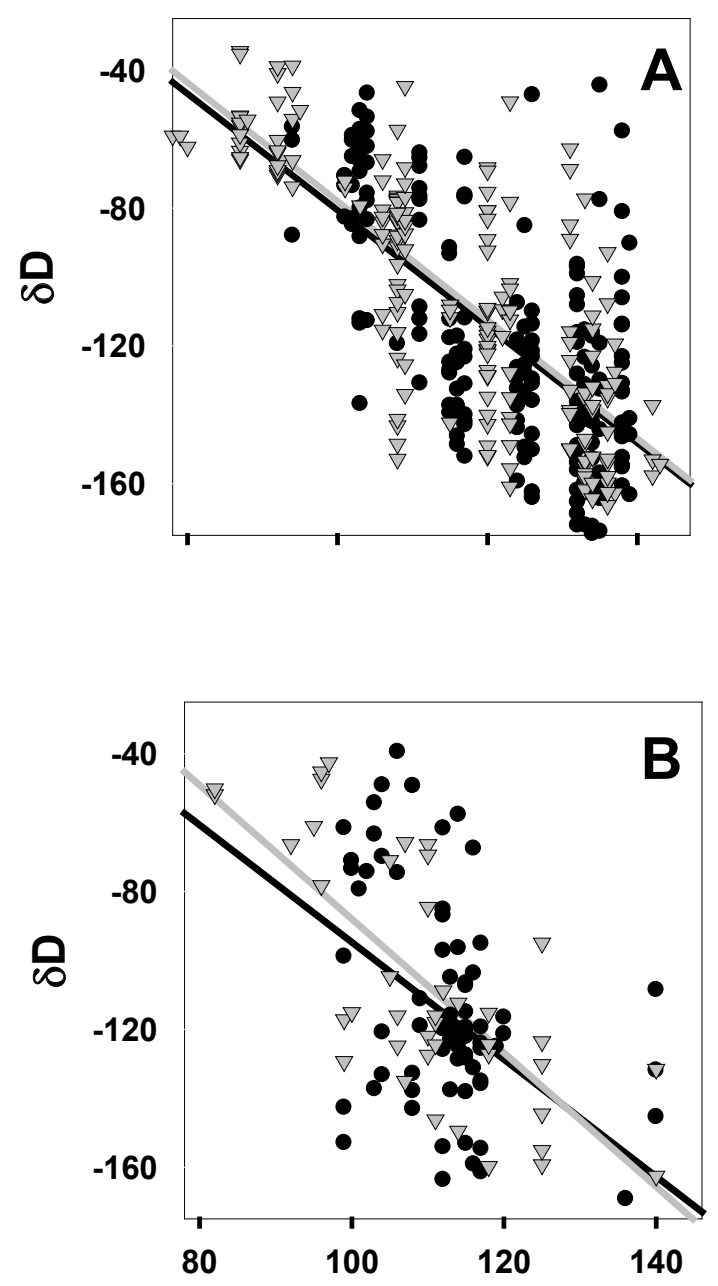

Figure 2.5. Timing of migration and $\delta D$ values in 2003 and 2004 at A) Lower Colorado River and B) Arivaca Creek. (2003 is represented by solid circles; 2004 by shaded triangles.) ANCOVA showed no difference in slopes and intercepts between the two years at either site.

indicate that there is a high degree of breeding site philopatry for Wilson's Warblers, at least at broad geographic scales, because feathers were collected only from adults that had not yet molted and therefore the $\delta \mathrm{D}$ value represented their breeding location the previous year. This contrasts with other studies (Chase et al. 1997) that found relatively low levels of philopatry at smaller geographic scales.

Consistent with continental patterns observed in $\delta \mathrm{D}$ of growing season precipitation (Ingraham 1998), $\delta \mathrm{D}$ values of feathers collected across the breeding grounds had a significant negative relationship with both latitude and elevation, confirming that more depleted values of $\delta \mathrm{D}$ occur at higher latitudes and elevations. While latitude contributes most to the pattern of $\delta \mathrm{D}$ values, elevation has the potential to confound the precision of determining breeding locations of warblers. Although models that incorporate elevation as a component in the map of $\delta \mathrm{D}$ values for growing season precipitation have reduced this error (Meehan et al. 2004), elevation in mountainous western North America makes determining geographic origins more complicated. For example, some of the scatter of $\delta \mathrm{D}$ values over the migratory season observed in this study could have been due to the confounding effect of elevation (Fig. 2.3). 


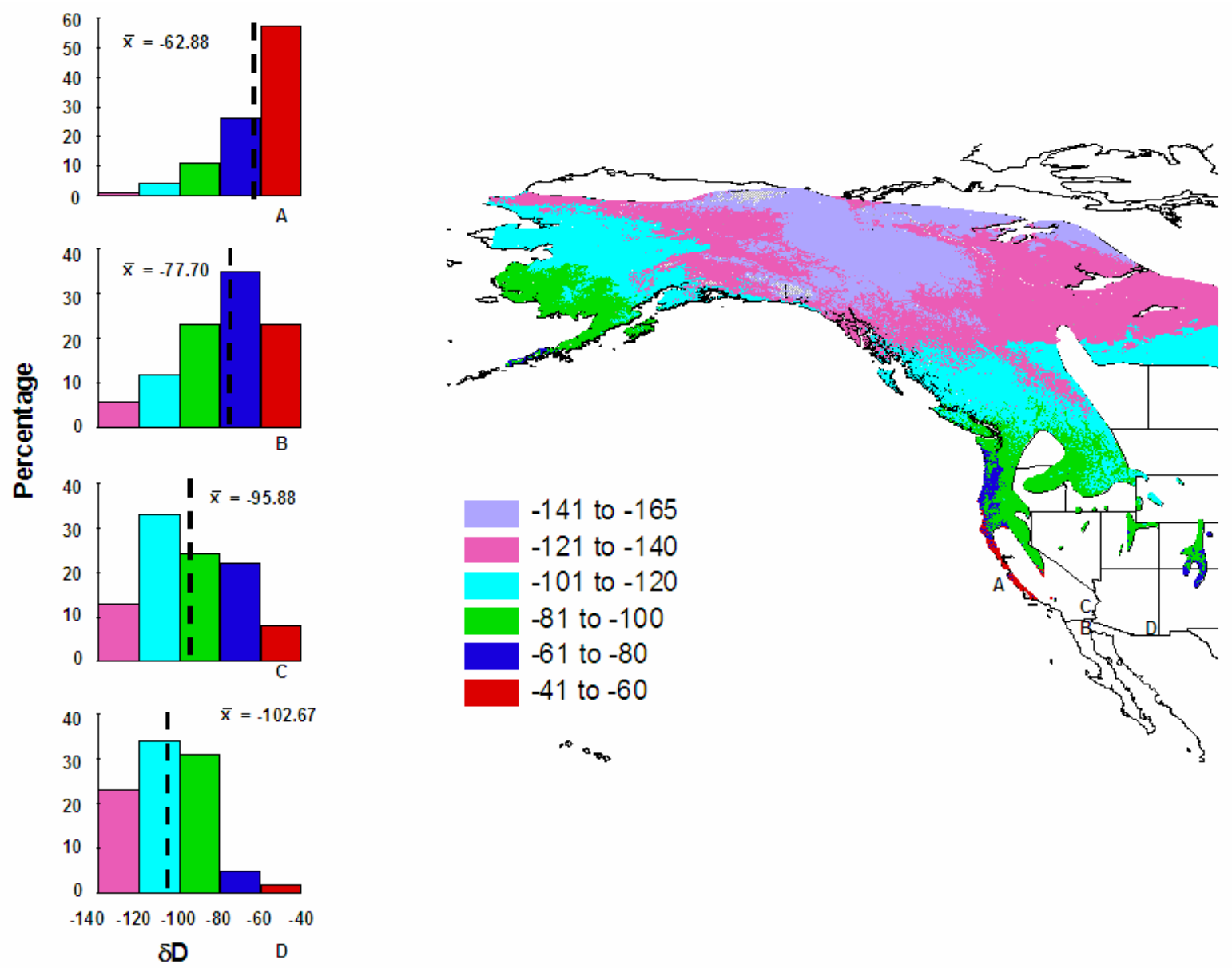

Figure 2.6. Map representing $\delta D$ values within Wilson's Warblers western breeding range. (Modified from Meehan et al. 2004.) Colors on map correspond to histograms of $\delta D_{x}$ values for A) Big Sur (2004), B) Colorado River Delta (2003), C) Lower Colorado River (2003) and, D) San Pedro (2003) migration stations. Mean $\delta D_{x}$ values (dotted lines) were significantly different among all sites except Lower Colorado River and Arivaca Creek (not shown). $\delta D_{x}$ values between -140 and $-159 \%$ (found only within the Yukon Territory) were not included in histograms because they represent less than $2 \%$ of the total warblers sampled for all sites combined.

\section{Timing of Migration with Respect to Breeding Location}

Comparison across multiple migration stations spanning the southwestern U.S. suggests that there is structure in the timing of Wilson's Warbler migration with respect to breeding locations. Warblers that bred the previous year at more southern locations migrated through the southwest earlier than did warblers that bred the previous year at more northern locations. Previous work on Wilson's Warblers' wintering distribution showed that the latitudinal sequence of $\delta \mathrm{D}$ on the wintering grounds is opposite that of the breeding grounds, i.e., warblers breeding at southern latitudes winter at more northern latitudes (Kelly et al. 2002b, Clegg et al. 2003). The combination of these data sets indicates a leapfrog migration for Wilson's Warblers during spring migration. Warblers wintering at the more northerly parts of Central America, migrate through first to breed at more southern latitudes of North America, and are leapfrogged by warblers migrating from more southern wintering locations to breed at more northern locations (Figure 2.7). Furthermore, this pattern was consistent from one year to the next. This finding further clarifies previous work 
that documented a similar pattern in the timing of migration in Wilson's Warblers passing through a single site in New Mexico in fall but not in spring (Kelly et al 2002a).

One migration site in this study, the San Pedro, showed the weakest relationship between timing of migration and $\delta \mathrm{D}$ values being only marginally significant. However, this relationship was consistent with the temporal patterns exhibited by the other sites. This weak relationship may have been due to the narrower range of $\delta \mathrm{D}$ values exhibited by warblers passing through this location, combined with an overall shorter time period during which warblers migrated. These same factors may explain why a previous study in New Mexico (Kelly et al. 2002b) failed to find a similar timing pattern for Wilson's Warblers in spring of one year. Although the range of $\delta \mathrm{D}$ values reported for the site in New Mexico is similar to those collected at the San Pedro site (Kelly et al. 2002b), direct comparison of $\delta \mathrm{D}$ values is not possible because of differences in the methods used to correct for non-exchangeable hydrogen.

Differential timing of migration for different sex and age classes was found in this study and is consistent with other migration studies for many neotropical migrants including Wilson's Warbler (Gauthreaux 1982, Francis and Cooke 1986, Otahal 1995, Yong et al. 1998, Woodrey 2000). The arrival date of males was consistently earlier than females at all sites, potentially due to differing selection pressures on breeding strategies between males and females (Gauthreaux 1982). While the temporal pattern was significant for both males and females, the differential timing between the sexes corresponded to a shift in the patterns of stable hydrogen isotopes between

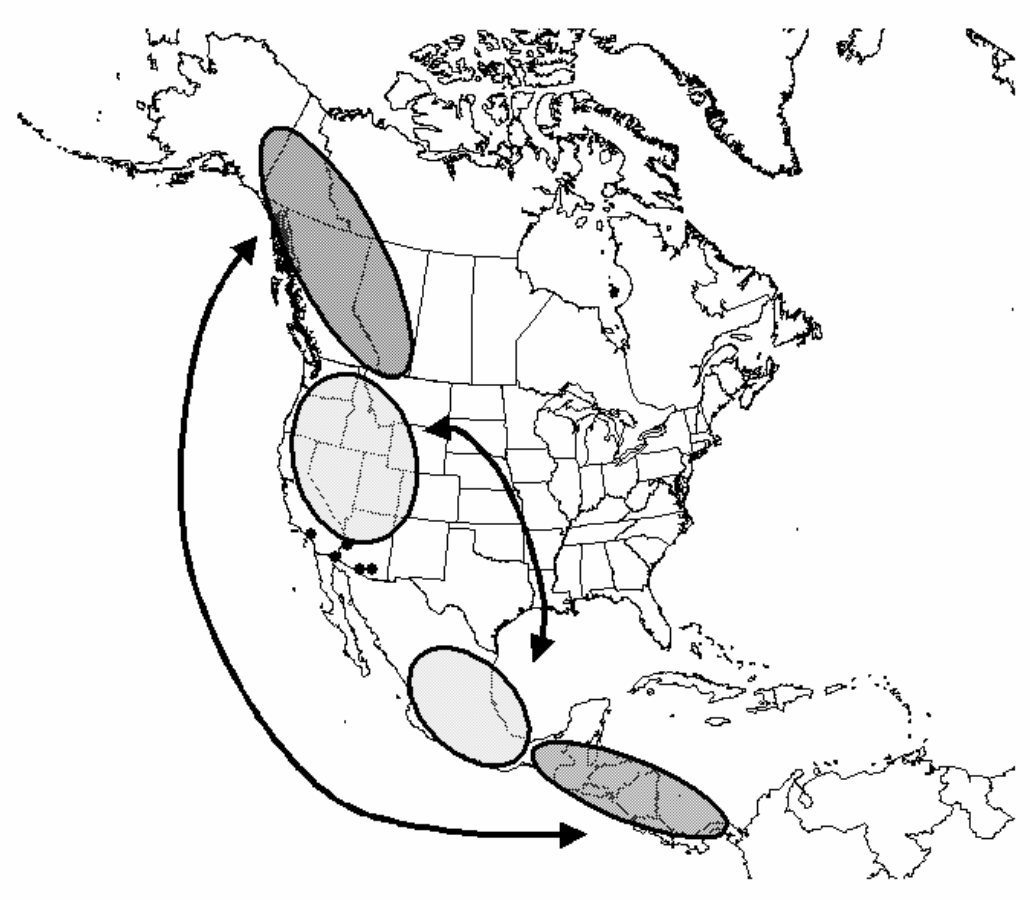

Figure 2.7. Demonstration of leapfrog migration for Wilson's Warblers. The latitudinal sequence of the breeding and wintering distributions are opposite, and warblers breeding at more southern locations migrate through the migration stations prior to warblers breeding at more northern locations. Black dots represent the 5 migration stations. 
males and females and accounts for some of the variation observed in the overall temporal pattern at each site. Likewise, the truncated time period of migration for second-year age classes also contributed to the variation observed in the temporal pattern found at the Lower Colorado River site. The timing patterns of different age and sex classes at other migration sites in the southwest are similar to the Lower Colorado River site, but further sampling is needed to determine the strength of these patterns at the other sites.

Documentation of leapfrog migration

for Wilson's Warblers during spring (this study) and fall (Kelly et al. 2002b) is important for two reasons. First, extrinsic and intrinsic factors controlling migration differ between spring and fall and, therefore, could potentially lead to different migration patterns. Seasonal differences in weather and prevailing winds can cause continental wide differences in migration pathways for neotropical migrant birds. This creates an overall clockwise migration pattern with bird migration pathways biased more westward in the spring and eastward in the fall (Bellrose and Graber 1963, Gauthreaux 1980, Moore et al. 1995). Evidence for these patterns has been found in both eastern and western migration systems (Phillips 1975, Crawford and Stevenson 1984, Rappole and Ramos 1994, Finch and Yong 2000, Hutto 2000). In addition, the differing constraints that fall and spring migration place on birds of different sexes and ages increases the potential for alternate migration patterns in these two seasons (Gauthreaux 1982, Yong et al. 1998). Even with these considerable differences between spring and fall migration, this study confirmed that leapfrog migration occurs during both seasons for Wilson's Warblers. Second, as pointed out by others (Kelly et al. 2002, Clegg et al.2003), leapfrog migration has a broader implication for the ecology and evolution of Wilson's Warblers. Differences in the distances traveled during migration for different breeding populations of this bird have the potential to act as a selective force shaping physiological and morphological traits, length of stay at migratory stopover sites, and breeding and wintering ecology. Understanding the migration strategy of Wilson's Warblers provides the basis to begin to test alternative models for the evolution of leapfrog migration (Greenberg 1980, Lundberg and Alerstam 1986, Holmgren and Lundberg 1993, Bell 1996, 1997) and potential differences in breeding, wintering, and migration strategies exhibited between western populations of Wilson's Warblers.

\section{Differences in $\delta D$ Among the Migration Stations}

Differences in $\delta \mathrm{D}$ values among the migration stations indicate that different breeding populations of Wilson's Warblers are using different migratory pathways across the migratory front from west to east. Wilson's Warblers from western migration stations (e.g. Big Sur and Colorado River Delta) were dominated by $\delta \mathrm{D}$ values consistent with breeding locations within coastal and Pacific slope regions, while the more eastern locations that we sampled (e.g., San Pedro) had larger proportions of warblers with $\delta \mathrm{D}$ values consistent with breeding locations in the western Canadian provinces and Alaska. Interior sites, such as the Lower Colorado River and Arivaca Creek, had warblers with a wide range of $\delta \mathrm{D}$ values, consistent with breeding locations across most of the western North America breeding range. Overall, this pattern indicates that warblers from different areas of the breeding range are using different migratory pathways, and suggests that habitat alteration at specific areas across the west-east expanse of the migratory route could differentially impact warblers at different breeding areas.

Detailed examination of the west-east pattern indicates that it is not a continuous gradient of change across the southwestern migration route, but that instead some sites in close proximity are more dissimilar than would be expected. For instance, the Colorado River Delta is $160 \mathrm{~km}$ southwest of the Lower Colorado River site, yet the latter is more similar in its range of $\delta \mathrm{D}$ values to Arivaca Creek, a site $440 \mathrm{~km}$ to the east. Likewise, Arivaca Creek is more similar to the Lower Colorado River site than the San Pedro site $200 \mathrm{~km}$ to the east (Fig. 2.1). These differences suggest that the broad west-east pattern is modified by other factors, such as topography and habitat features, which together play a role in shaping migratory routes across the southwest. For example, the Colorado River Delta and the Lower 
Colorado River locations are separated by the Sand Hills and Chocolate Mountains, ranges with main axes oriented northwest/southeast. In the same manner, the San Pedro site lies within the Sierra Madre Mountain range extending from Mexico into the U.S. and is at a much higher elevation than Arivaca Creek which lies at a lower elevation at the foothills of this mountain range. Dry, desert mountain ranges like these may serve as migratory corridor boundaries, separating lower elevation areas with more suitable stop-over habitat.

Wilson's Warblers migrating through the migration stations sampled in this study are assumed to be the two western subspecies $W$. $p$. pileolata and $W$. p. chryseola and not the eastern subspecies $W$. p. pusilla. During migration these subspecies cannot be accurately distinguished by morphological characteristics. This assumption is based on two factors. First, documentation of a distinct migration route in the east showing a circum-gulf migration in Texas and passage of warblers to the west of the Appalachian Mountains up to the Great Lakes indicates separate migration pathways between western and the most eastern populations of Wilson's Warblers (Ammon and Gilbert 1999). The migration pathways to more central breeding areas are less clear, however, and to account for this we have included in this analysis breeding locations as far west as the Canadian Province of Saskatchewan. Second, the $\delta \mathrm{D}$ values of the eastern breeding range are primarily between -60 and $-100 \%$ with a small proportion in the most northern breeding locations occurring as high as $-110 \%$. The $\delta \mathrm{D}$ values of the eastern breeding range are more consistent with $\delta \mathrm{D}_{\mathrm{x}}$ values of warblers migrating through the western migration stations in this study. Yet, the most likely site to have eastern migrants would be the San Pedro migration station where the $\delta \mathrm{D}_{\mathrm{x}}$ values of the majority of warblers $(60 \%)$ were consistent with values found only within Alaska and the western Canadian Provinces. However, a small percentage of warblers migrating through the San Pedro migration station have $\delta \mathrm{D}$ values consistent with breeding locations found in the either the intermountain west or eastern breeding locations and therefore could represent some $W . p$. pusilla.

While stable hydrogen isotopes delineate geographical patterns on a latitudinal scale relatively well, these data indicate that a combination of methods is necessary to distinguish among breeding areas across longitudes in the western United States (for example, a warbler migrating to breeding grounds in the Sierra Nevada Mountains of California could not be distinguished from one migrating to the Rocky Mountains in Colorado by $\delta \mathrm{D}$ alone). Although combining $\delta \mathrm{D}$ with other stable isotopes such as $\delta^{13} \mathrm{C}$ and $\delta^{87} \mathrm{Sr}$, could potentially provide more resolution in determining geographic origins of migrating warblers, thus far they have not provided more insight into distinguishing geographic origins of Wilson's Warblers within western populations. For example, Wilson's Warblers breed within riparian and forested habitats that are dominated by $\mathrm{C}_{3}$ plants and contain few if any $\mathrm{C}_{4}$ plants (Ammon and Gilbert 1999). While the range of $\delta^{13} \mathrm{C}$ within $\mathrm{C}_{3}$ plants varies from xeric to mesic environments (Farquhar et al. 1989), we found that there was no difference between $\delta^{13} \mathrm{C}$ values of Wilson's Warblers' feathers grown in mesic environments such as coastal habitats and more xeric environments found in the intermountain west. To date, there have been no studies examining possible variations in $\delta^{87} \mathrm{Sr}$ or other stable isotopes across a large geographic scale from bird feathers grown in the western United States. Likewise, linking isotopes with current genetic data sets also appears to have limited utility. Studies using both mitochondrial and nuclear DNA markers to explore phylogeographic patterns in Wilson's Warblers found strong divergence between eastern and western breeding populations, but could not discriminate among breeding populations within the western range (Kimura et al. 2002, Clegg et al. 2003). Development of other genetic markers, sampling of different stable isotopes in the west, and the combination of other techniques used in conjunction with $\delta \mathrm{D}$ may provide in the future more precise estimates of geographic origins of neotropical migrants.

\section{Conservation Implications}

Habitat alterations at specific areas across the east-west expanse of Wilson's Warblers' migratory route could differentially impact warblers from different breeding areas. This is critical information for the management of neotropical 
migrants, especially in light of the rapid changes to the landscape of the southwest in the last century. One of the most heavily disturbed habitat types in the southwest is riparian habitat, which comprises less than $1 \%$ of the landscape, but supports the largest abundance and diversity of birds (Johnson et al. 1977, Knopf 1988, Finch and Ruggiero
1993) and is critical stopover habitat for many neotropical migrants (Stevens et al. 1977, Rich et al. 2004). This study suggests that loss of specific habitats across the west-east migratory could differentially affect specific breeding populations, and could result in very localized reduction in Wilson's Warbler numbers. 


\section{Chapter 3. Migration Patterns Revealed by Stable Isotopes for MacGillivray's and Nashville Warblers in the Southwestern United States}

Understanding large-scale migration patterns for migrating birds is hindered by the difficulty of following individuals and populations throughout the entire year (Webster et al. 2002), and this is particularly true of the smaller warbler species. In particular, tracking neotropical songbirds over large distances by traditional methods (e.g., banding) has produced too few band returns to yield robust information. Recent studies have shown that the measurement of naturally occurring stable isotopes in animal tissues can be used to delineate geographically distinct populations (Chamberlain et al. 1997, Hobson and Wassenaar 1997, Marra et al. 1998). For example, stable hydrogen isotope ratios $(\delta \mathrm{D})$ in the tissues of animals are often correlated with the stable hydrogen isotope ratios of local precipitation (Chamberlain et al. 1997, Hobson and Wassenaar 1997, Kelly et al. 2002b). This relationship is primarily driven by latitude, as southern latitudes are more enriched with $\delta \mathrm{D}$ than are northern latitudes (Ingraham 1998). In most species of birds, the isotopic signature of feathers reflects the diet of the birds only during the period of growth.

Since many species of migrant warblers, including the focal species in this study: MacGillivray's Warbler (Oporornis tolmiei) and Nashville Warbler (Vermivora ruficapilla), molt their feathers on or near their breeding grounds before migration (Pyle 1997), the isotopic signature of their feathers should reflect the isotopic signature of that breeding site.

Using stable hydrogen isotopes, we examined migration patterns of MacGillivray's and Nashville Warblers during spring migration at multiple sites within their southwestern migration route. MacGillivray's Warblers migrate through the southwest to breeding locations primarily within either the Rocky Mountains and their eastern foothills, or the coastal regions extending from coastal California to northern British Columbia (Fig. 3.1). The migration time period is poorly understood for MacGillivray's Warblers because of their elusive and secretive behavior and preference for dense undergrowth during migration (Pitocchelli 1995). In contrast, the western subspecies of Nashville Warblers (Vermivora ruficapilla ridgwayi) breed within a small geographic region within the west (Williams 1996) (Fig 3.2). Research during the migration time period for Nashville Warblers within the southwest indicated that their migration patterns were unpredictable and concentrated in more western migration locations (i.e., at more western migration sites they appeared in large numbers some years and were absent others, while at eastern migration sites numbers were consistently low) (van Riper and Ecton, USGS unpublished data). The goals of this study were to use stable hydrogen isotopes to determine how the spatial and temporal patterns of migration for MacGillivray's and Nashville Warblers were related to breeding locations. In addition, for MacGillivray's Warbler, we examined the strength of the correlation between stable hydrogen isotope values of MacGillivray's Warbler feathers and the local precipitation at sites where feathers where collected across the breeding range, and the spatial distribution of MacGillivray's Warblers on the wintering grounds.

\section{Methods}

\section{Study Area}

To determine the relationship between $\delta \mathrm{D}$ values of MacGillivray's Warbler feathers (collected by the UCLA Conservation Genetics Resource Center) from the breeding grounds and local precipitation where the birds were captured, $\delta \mathrm{D}$ values were determined from a single rectrix collected from 22 MacGillivray's Warblers across their breeding grounds between 1996 and 2002 (Table 3.1, Fig. 3.1). All feathers were from adult males and females. To ensure that these feathers were from breeding individuals, only warblers captured between 15 June and 15 Aug were included. A GIS-derived map of $\delta \mathrm{D}$ values for growing season precipitation across North America 
(Meehan et al. 2004) was used to obtain $\delta \mathrm{D}$ values of local precipitation where breeding warblers were sampled. This information was not collected for Nashville Warblers because an adequate sample size on the breeding grounds could not be obtained.

MacGillivray's Warbler feathers were also collected across their wintering range at 6 locations $(n=30)$ between 1996 and 1998 (Fig. 3.1) feathers were provided by the UCLA Conservation Genetics Resource Center). Feathers were collected between 1 December and 1 February to ensure only wintering individuals were sampled. A single rectrix from each sample was analyzed for $\delta \mathrm{D}$ to assess wintering distribution patterns of MacGillivray's Warblers.

We captured MacGillivray's and Nashville Warblers during spring migration between 15 March and 1 June 2003 at four sites: Colorado River Delta in Baja California, Mexico; Lower Colorado River at Cibola National Wildlife Refuge (NWR) in southwestern Arizona; Arivaca Creek at Buenos Aires NWR in southeastern Arizona; and
San Pedro River at San Pedro Riparian National Conservation Area in southwestern Arizona. Only two sites obtained a large enough sample size for analysis, and thus will be the focus of the remaining paper (Colorado River Delta and Lower Colorado River). Warblers were caught by passive mistnetting, banded, standard morphological measurements taken, and an outer rectrix from each side of the tail pulled for stable isotope analysis. Feathers were stored in labeled, sealed envelopes until analyzed.

\section{Stable Isotope Analysis}

Feathers were washed in detergent and thoroughly rinsed to remove oil, dirt, and residual detergent (Chamberlain et al. 1997, Kelly et al. 2002), and then air-dried at room temperature. Feather material from the distal end $(0.33-0.37 \mathrm{mg})$ was removed and wrapped in a silver capsule for isotopic analysis. Due to the problem of uncontrolled isotopic exchange between approximately $13 \%$ of non-carbon-bound hydrogen

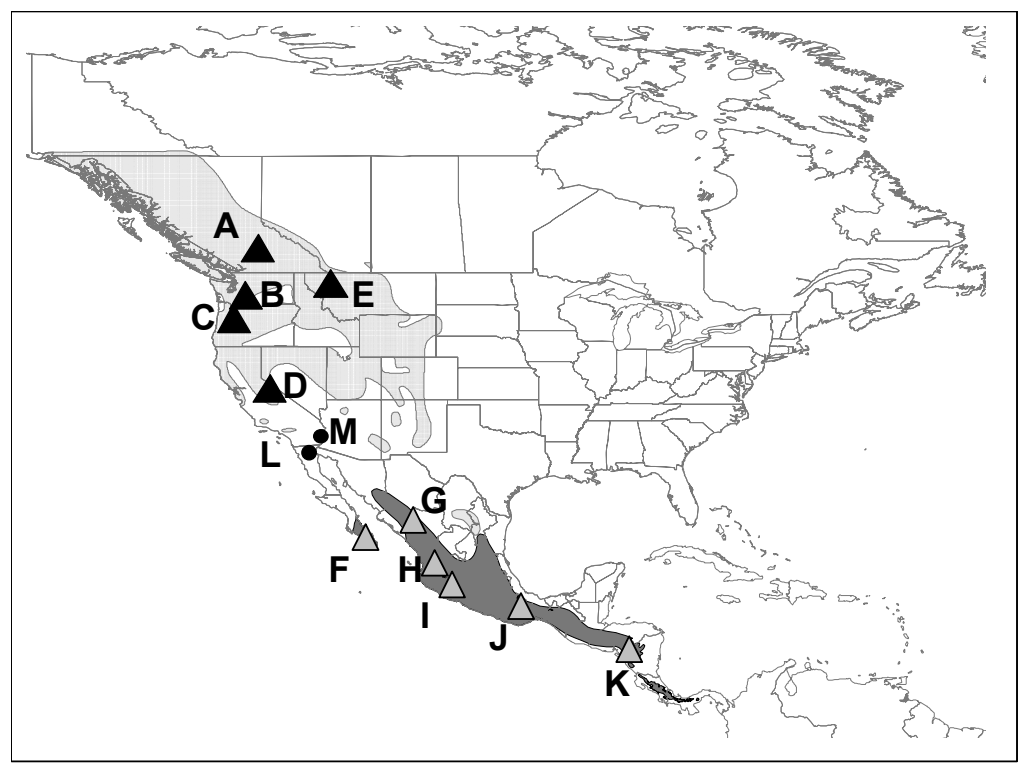

Figure 3.1. Location of breeding, migration, and wintering stations where MacGillivray's Warblers feathers were collected. (See Table 3.1 for site information.) Light gray and dark gray shaded regions indicate MacGillivray's Warblers breeding and wintering range respectively. Black triangles represent sites where feathers were collected on breeding ground, circles represent migration stations, and gray triangles represent where feathers were collected on the wintering grounds. 
Table 3.1 Sampling locations and sample size $(n)$ for breeding, wintering, and migration stations for MacGillivray's Warblers. Average stable hydrogen isotope values $(\delta D)$ indicated for each site.

\begin{tabular}{llcc}
\hline Sampling Site & Latitude-Longitude & $n$ & $\delta \mathrm{D}(\underline{\underline{t}} \mathrm{SD})$ \\
\hline Breeding & & & \\
A. 100 MileHouse, British Columbia & $51^{\circ} 39^{\prime} \mathrm{N} 121^{\circ} 17^{\prime} \mathrm{W}$ & 4 & $-135(7.19)$ \\
B. Wenatchee National Forest, WA & $46^{\circ} 56^{\prime} \mathrm{N} 121^{\circ} 04^{\prime} \mathrm{W}$ & 4 & $-120.08(5.1)$ \\
C. Willamette National Forest, OR & $44^{\circ} 15^{\prime} \mathrm{N} 122^{\circ} 00^{\prime} \mathrm{W}$ & 4 & $-84.51(5.57)$ \\
D. Tahoe National Forest, CA & $39^{\circ} 37^{\prime} \mathrm{N} 120^{\circ} 31^{\prime} \mathrm{W}$ & 5 & $-84.84(4.6)$ \\
E. Flathead National Forest, MT & $48^{\circ} 23^{\prime} \mathrm{N} 114^{\circ} 02^{\prime} \mathrm{W}$ & 5 & $-120.73(4.4)$ \\
& & & \\
Wintering & & & \\
F. Baja California Sur, Mexico & $22^{\circ} 53^{\prime} \mathrm{N} 109^{\circ} 54^{\prime} \mathrm{W}$ & 4 & $-85.16(5.9)$ \\
G. Sinola, Mexico & $23^{\circ} 50^{\prime} \mathrm{N} 102^{\circ} 20^{\prime} \mathrm{W}$ & 6 & $-96.32(6.93)$ \\
H. Jalisco, Mexico & $19^{\circ} 46^{\prime} \mathrm{N} 104^{\circ} 22^{\prime} \mathrm{W}$ & 7 & $-104.94(9.31)$ \\
I. Michoacan, Mexico & $18^{\circ} 45^{\prime} \mathrm{N} 102^{\circ} 54^{\prime} \mathrm{W}$ & 4 & $-105.58(6.14)$ \\
J. Oaxaca, Mexico & $17^{\circ} 03^{\prime} \mathrm{N} 96^{\circ} 43^{\prime} \mathrm{W}$ & 6 & $-109.42(7.1)$ \\
K. San Salvador, El Salvador & $13^{\circ} 42^{\prime} \mathrm{N} 89^{\circ} 12^{\prime} \mathrm{W}$ & 5 & $-115.27(7.12)$ \\
& & & \\
Migration & & & \\
L. Colorado River Delta, Baja California, MX & $32^{\circ} 18^{\prime} \mathrm{N} 115^{\circ} 20^{\prime} \mathrm{W}$ & 14 & $-63.26(13.62)$ \\
M. Lower Colorado River, AZ & $33^{\circ} 18^{\prime} \mathrm{N} 114^{\circ} 41^{\prime} \mathrm{W}$ & 22 & $-62.45(14.98)$ \\
\hline
\end{tabular}

in feathers and ambient water vapor (Chamberlain et al. 1997), we used a comparative equilibrium approach with calibrated keratin standards to correct for this effect. As a result, values presented in this paper are non-exchangeable feather hydrogen only. Details of this method and standards used are described in Wassenaar and Hobson (2003). Unlike past methods to control for non-exchangeable feather hydrogen, this method allows for comparisons of $\delta \mathrm{D}$ values among laboratories.

All stable isotope analysis was conducted at the Colorado Plateau Stable Isotope Laboratory located at Northern Arizona University. Hydrogen stable isotope ratios for both feathers and keratin standards were determined on $\mathrm{H}_{2}$ gases, produced by high temperature flash pyrolysis of feathers using a Thermo Finnigan High TemperatureConversion Elemental Analyzer $\left(1400{ }^{\circ} \mathrm{C}\right)$ interfaced through an open split (Finnigan Conflo II) with a continuous flow isotope ratio mass spectrometer (Finnigan Delta Plus XL). The stable hydrogen isotope ratios $\left({ }^{2} \mathrm{H} /{ }^{1} \mathrm{H}\right)$ are all presented in delta $(\delta)$ notation:

$\delta \mathrm{D}_{\text {sample }}=\left[\left(\mathrm{R}_{\text {sample }} / \mathrm{R}_{\text {standard }}\right)-1\right] \times 1000$
Results for $\delta \mathrm{D}$ are expressed in per mil notation (\%) relative to a standard, VSMOW. Repeat analyses of internal hydrogen isotope standards yielded an external repeatability of $\pm 2.3 \%$.

\section{Statistical Analysis}

We utilized linear regression to examine the relationship between timing of migration and putative breeding location based on $\delta \mathrm{D}$. We also examined the difference in $\delta \mathrm{D}$ values between the two sampling stations using an independent t-test. These two analyses were conducted for MacGillivray's and Nashville Warblers. For MacGillivray's Warbler we also examined how potential differences in the $\delta \mathrm{D}$ ranges between the sampling stations related to breeding locations within MacGillivray's Warblers' breeding range. We used the GIS map of $\delta \mathrm{D}$ values of precipitation across North America (Meehan et al. 2004) and clipped out the MacGillivray's Warblers' breeding range so that we could query $\delta \mathrm{D}$ values only within this geographical area. To determine where MacGillivray's Warblers migrating through our capture locations occurred within their breeding range, we used the regression 


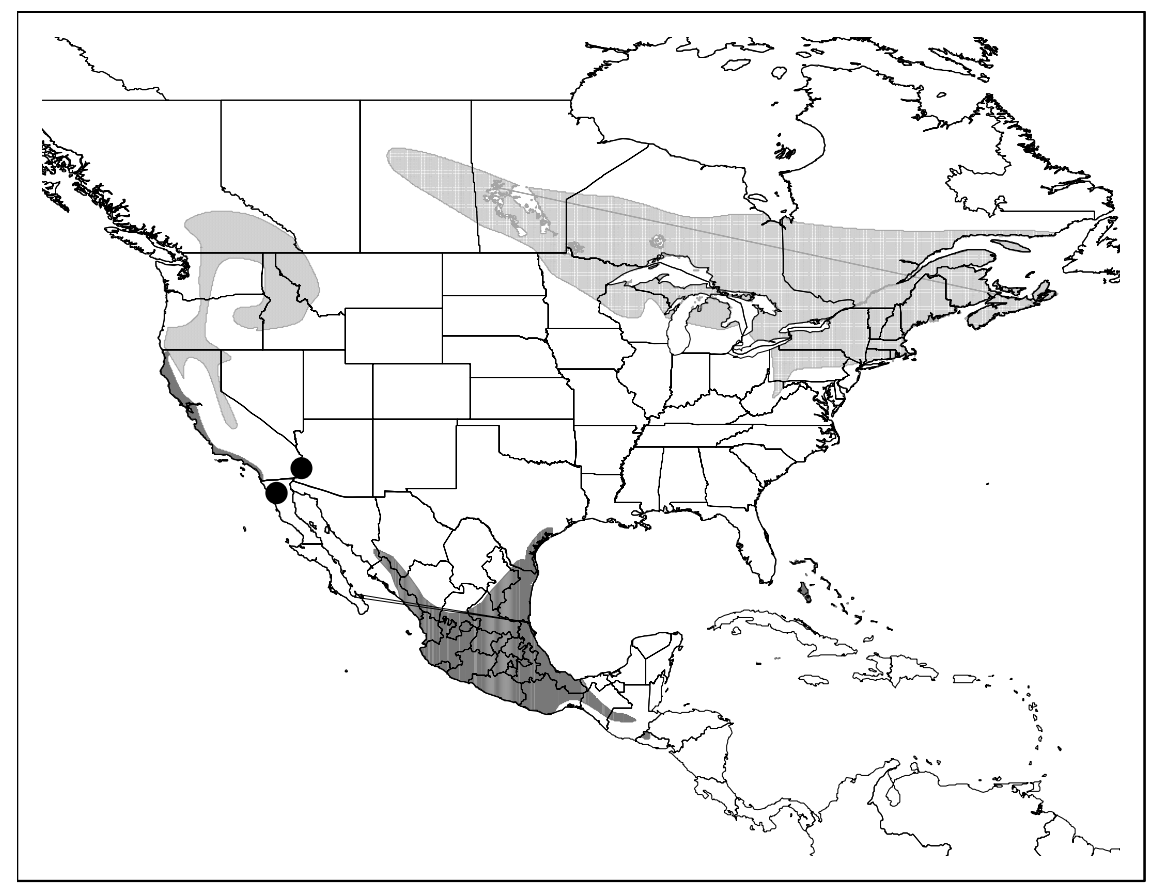

Figure 3.2. Breeding and wintering distribution of Nashville Warblers and migration stations where feathers were collected. Light gray and dark gray shaded regions indicate breeding and wintering range, respectively. Black circles represent migration stations where Nashville Warblers were sampled.

equation that expressed the relationship between $\delta \mathrm{D}$ of feathers $\left(\delta \mathrm{D}_{\mathrm{f}}\right)$ and $\delta \mathrm{D}$ of local precipitation $\left(\delta \mathrm{D}_{\mathrm{p}}\right)$ to estimate the $\delta \mathrm{D}$ of warblers caught at the migration stations $\left(\delta \mathrm{D}_{\mathrm{x}}\right)$. To be conservative and account for error within the regression model and the deuterium map, we queried $\delta \mathrm{D}$ values from the GIS map within $20 \%$ ranges. All GIS analyses were done with ArcGIS 8.2. All statistical analyses were conducted with SPSS v12.0, 2003, and significance for statistical tests was assessed at $\mathrm{p} \leq$ 0.05 .

\section{Results and Discussion}

\section{Relationship Between $\delta D$ of Feathers and Precipitation}

We found a significant positive relationship between the $\delta \mathrm{D}_{\mathrm{f}}$ of MacGillivray's Warblers' feathers and $\delta \mathrm{D}_{\mathrm{p}}$ where warblers were captured $\left(\mathrm{F}_{1,20}=240.19, \stackrel{\mathrm{p}}{\mathrm{P}}<0.001, \mathrm{R}^{2}=0.92\right)$ (Fig. 3.3), consistent with data indicating MacGillivray's Warblers molt their feathers on or near their breeding grounds (Pyle 1997). The relationship was not 1:1 across the breeding range, indicating that either there is a difference in the fractionation rates between the low and high latitude sites, or the accuracy of the interpolated $\delta \mathrm{D}$ values from the precipitation map varies between high and low latitudes due to differences in the number of precipitation stations sampled within these locations.

\section{Spatial Distribution of Wintering Populations}

We found a significant positive relationship between $\delta \mathrm{D}$ values of feathers collected on the wintering grounds and the latitude of the winter collection site $\left(\mathrm{F}_{1,28}=30.29, \mathrm{P}<0.001, \mathrm{R}^{2}=0.52\right)$ (Fig. 3.4). Because the $\delta \mathrm{D}$ value of MacGillivray's feathers reflects the $\delta \mathrm{D}$ value of their breeding locations, with more negative values representing more northerly breeding latitudes, this positive 


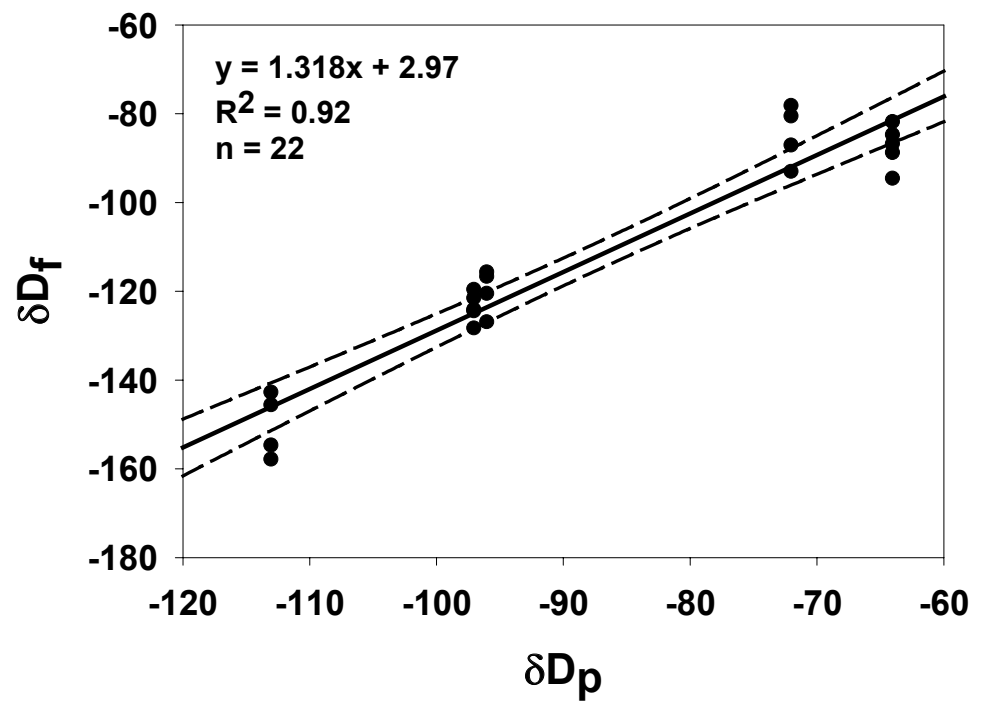

Figure 3.3. Regression showing the relationship between stable hydrogen isotopes of MacGillivray's Warbler feathers $\left(\delta D_{f}\right)$ collected on their breeding grounds and the growing season precipitation $\left(\delta D_{p}\right)$ where warblers were captured. Dashed lines represent the $95 \%$ confidence intervals.

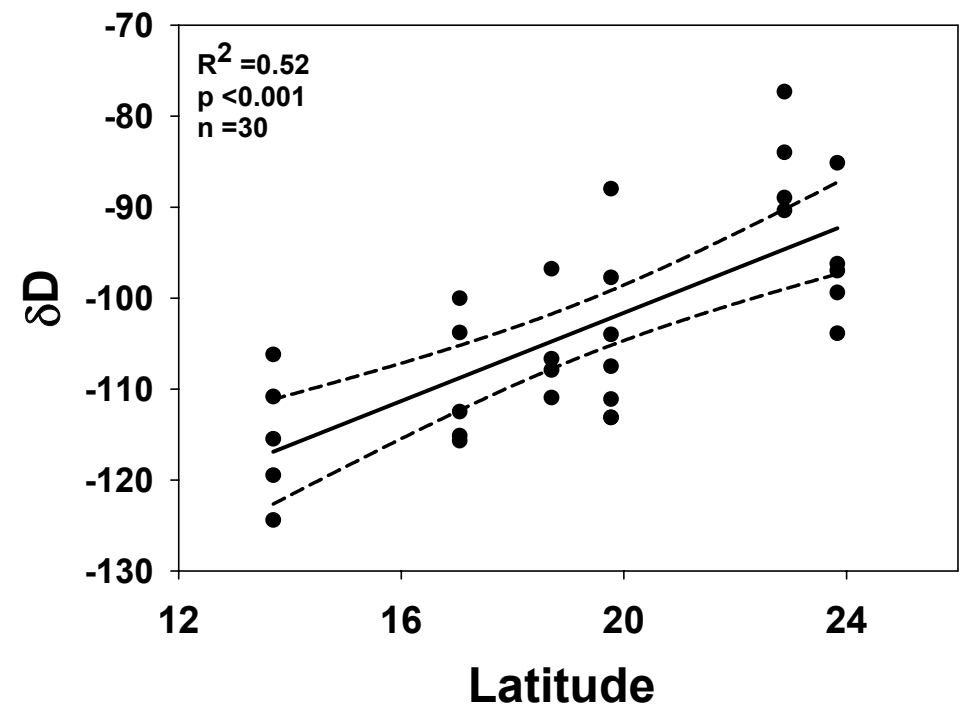

Figure 3.4. Regression showing the relationship between stable hydrogen isotopes of MacGillivray's Warbler feathers $(\delta D)$ collected on their wintering grounds and the latitude where warblers were captured. Dashed lines represent the $95 \%$ confidence intervals. 
relationship between feather $\delta \mathrm{D}$ and wintering latitude indicates that warblers wintering at more southern latitudes bred at more northern latitudes.

\section{Timing of Migration with Respect to Breeding Location}

There was a significant negative relationship between the date when MacGillivray's Warblers passed through the sampling station and $\delta \mathrm{D}$ values of their feathers (Fig. 3.5). These data indicate that warblers that bred the previous season at southern latitudes migrated through the migration stations earlier than warblers that had previously bred at more northern latitudes. There was not a large enough sample size to test for differences between males and females. Both the Lower Colorado River $\left(\mathrm{F}_{1,183}=128.47, \mathrm{P}<0.006, \mathrm{R}^{2}=0.32\right)$ and the Colorado River Delta $\left(\mathrm{F}_{1,12}=11.96, \mathrm{P}<0.005, \mathrm{R}^{2}=\right.$ $0.50)$ showed the same significant relationship. This is the first study to indicate that migration for MacGillivray's Warblers is temporally structured with respect to their breeding location,
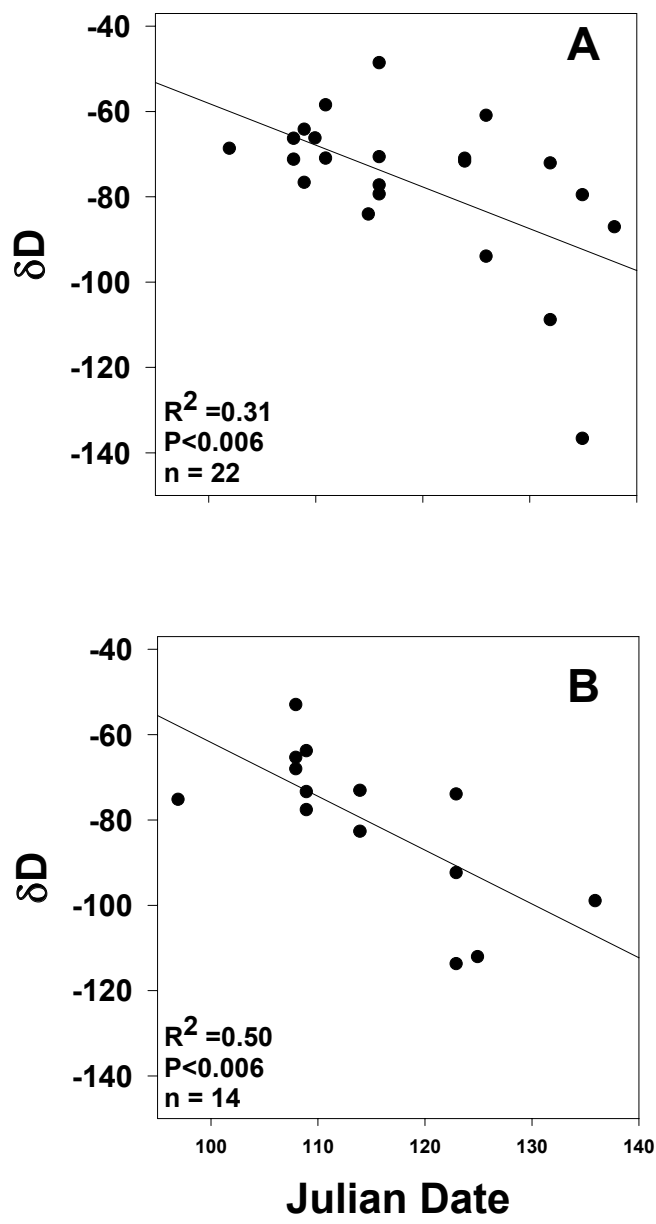

Figure 3.5. Relationship between the timing of migration and $\delta D$ values of MacGillivray's Warblers for two sites. Regression of $\delta D$ of migrating MacGillivray's Warblers by date, for each site, shows a negative relationship between the timing of migration and $\delta D$ of migrating warblers with warblers arriving earlier in the season having more enriched values of $\delta D$. Migration sites are A) Lower Colorado River and B) Colorado River Delta. $\delta D$ values that are more negative or depleted represent more northern breeding locations while more positive or enriched $\delta \mathrm{D}$ values represent more southern breeding locations. 

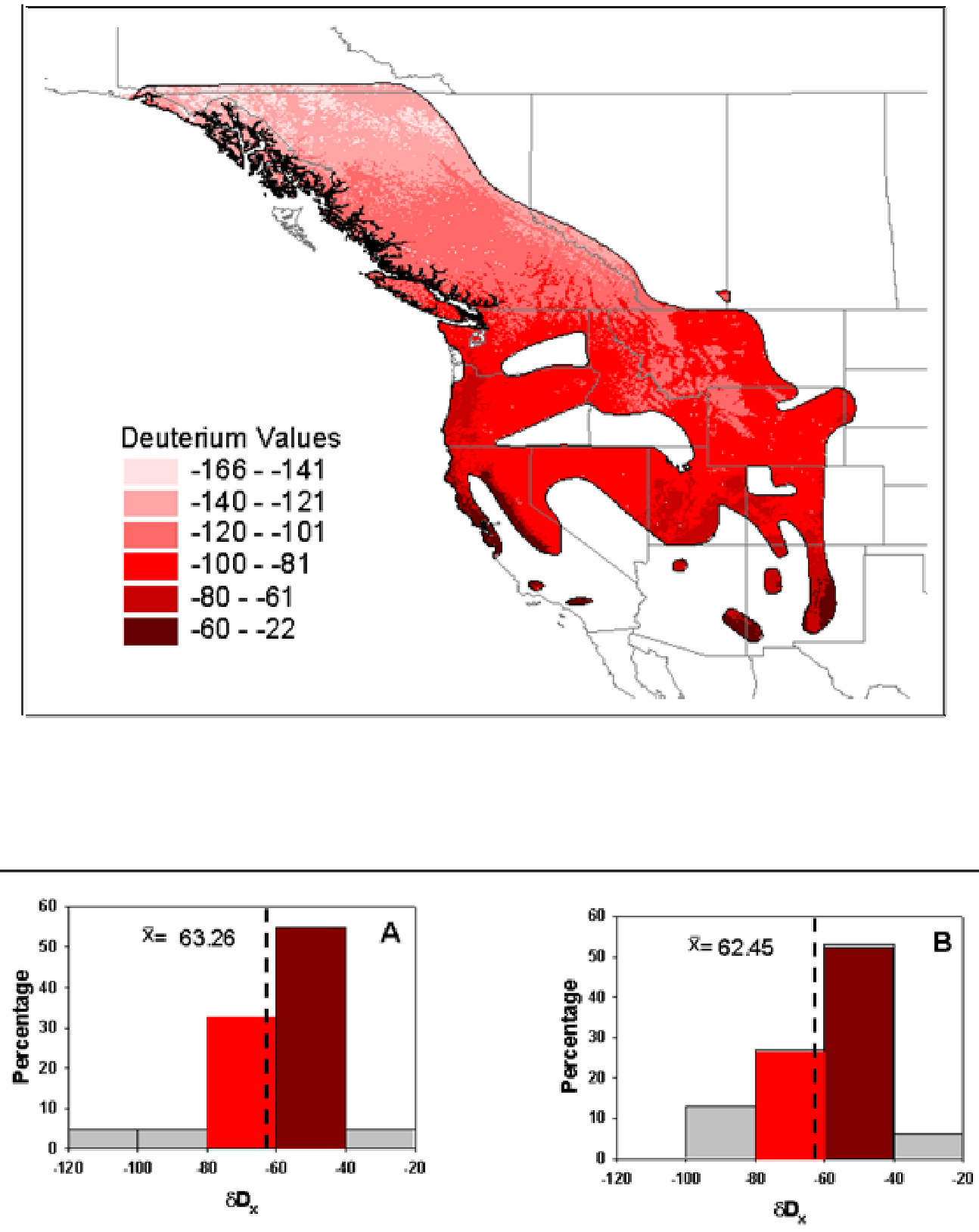

Figure 3.6. Map representing $\delta D$ values found within MacGillivray's Warblers breeding range. (Modified from Meehan et al. 2004.) Colors on map correspond to histograms of $\delta D x$ values for A) Lower Colorado River and B) Colorado River Delta stations. 

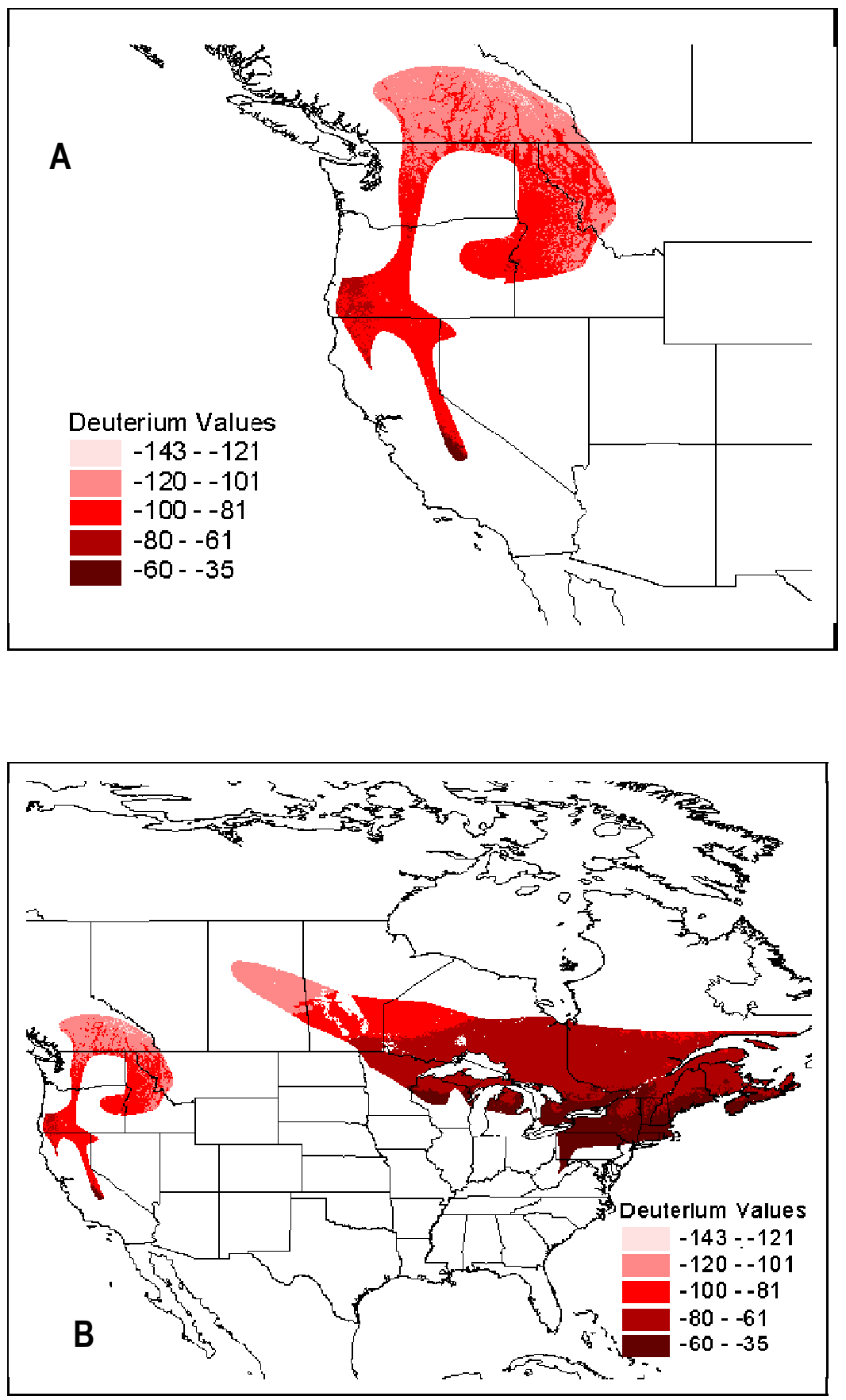

Figure 3.7 Maps representing $\delta D$ values found within Nashville Warblers breeding range. A) $\delta D$ values found within Nashville Warblers western breeding range. B) $\delta$ D values found within Nashville Warblers eastern and western breeding range. 
and is consistent with temporal patterns that we documented earlier in this report.

However, we found no significant relationship between the date when Nashville Warblers passed through the sampling station and $\delta \mathrm{D}$ values of their feathers for both the Lower Colorado River $\left(\mathrm{F}_{1,48}=2.11, \mathrm{P}=0.15\right)$ and Colorado River Delta $\left(\mathrm{F}_{1,10}=0.32, \mathrm{P}=0.58\right)$ sites. The lack of temporal pattern for Nashville Warbler could be due to the reduced size of both the breeding and wintering ranges of Nashville Warblers decreasing the advantages of a temporal migration pattern. There is also a small population of Nashville Warblers that breed on the California coast. The sporadic nature of migration for Nashville Warblers in the southwest suggests that in some years more Nashville Warblers winter along the coast of California. Further research would be required to test this hypothesis.

\section{Differences in $\delta D$ Between the Migration Stations}

The geographic distribution of $\delta \mathrm{D}$ values within MacGillivray's Warblers' breeding range formed distinct regions within $20 \%$ ranges (Fig. 3.6). The $\delta \mathrm{D}$ values between -22 to $-60 \%$ occur along the California Coast and the western range of the Sierra Nevada Mountains within the western portion of MacGillivray's breeding range, and only within the southern most breeding sites in Arizona and New Mexico in the eastern portion of their breeding range. Values between -61 to $-80 \%$ correspond with the Pacific Slope Region and a small portion of the range in the mountains of Utah, New Mexico, and Colorado. The Intermountain West Region is predominately $\delta \mathrm{D}$ values between -81 to $-100 \%$. $\delta \mathrm{D}$ values between -101 to $-120 \%$ occur within the southern region of British Columbia, while $\delta \mathrm{D}$ values between 121 to $-140 \%$ are found only within the northern region of British Columbia, and a small percentage of the breeding range in the northernmost regions of British Columbia have $\delta \mathrm{D}$ values between -141 to $-160 \%$.
Comparison of the spatial distribution of $\delta D_{x}$ values for MacGillivray's Warblers between our two study sites showed that there was not a significant difference between the mean $\delta D_{x}$ values $(t=0.166, P=0.87)$. In fact the $\delta \mathrm{D}_{\mathrm{x}}$ values of the majority of warblers migrating through these stations corresponded to the same regions within the breeding range Figure 3.6). At the Lower Colorado Site and the Colorado River Delta, 55\% and 53\%, respectively, of the McGillivray's Warblers migrating through these stations had $\delta \mathrm{D}_{\mathrm{x}}$ values consistent with those along the California coast and the western slopes of the Sierra Nevada Mountains. Approximately $35 \%$ and $26 \%$, respectively, of the warblers had values like that of the Pacific Slope Region or a small portion of the range in the mountains of Utah, New Mexico, and Colorado. These data indicate that breeding populations from a restricted region of MacGillivray's Warblers' breeding range are migrating through these two sites. This is in contrast to the range of $\delta \mathrm{D}$ values for Wilson's Warblers at these two sites which was consistent with a broader area across their breeding range, particularly at the Lower Colorado River site.

The geographic distribution of $\delta \mathrm{D}$ values within Nashville Warblers' western breeding range doesn't form into distinct regions because of the narrow configuration of breeding locations, but $\delta \mathrm{D}$ values do become more negative or depleted with increasing latitude (Fig. 3.7a). This is in contrast to the eastern breeding range, which forms distinct regions within $20 \%$ ranges (Figure 3.7b). The range of $\delta \mathrm{D}$ values for both the Lower Colorado River and Colorado River Delta sites (-40 to -130 $\%$ ) indicates that warblers from all regions of the western breeding range are migrating through these two stations. The highest abundance of warblers occurs within the -81 to $-100 \%$ range, also the most abundant $\delta \mathrm{D}$ values across the breeding range. 


\section{Chapter 4. Conclusions}

Results from feathers collected at breeding, wintering, and migration stations indicated that MacGillivray's Warbler, like Wilson's Warbler, exhibit a leapfrog migration pattern in which warblers wintering at more northern latitudes pass through migration stations in the southwest first, and are then leapfrogged by more southern wintering populations that are migrating to northern breeding locations. This is the first documentation of leapfrog migration for MacGillivray's Warbler. The spatial distribution of MacGillivray's Warbler at the two study sites also indicated that warblers migrating though migration stations within their central migration route are breeding within a restricted range. Intense collection of more feathers at multiple migration stations would aid in distinguishing spatial migration patterns across their entire migration route.

The use of stable hydrogen isotopes to examine spatial and temporal migration patterns for Nashville Warblers provided limited utility in this study. The reduced range of $\delta \mathrm{D}$ values across the small western breeding range diminishes the power of stable isotopes as a tool for understanding migration patterns of Nashville Warblers in western North America. Further studies determining where Nashville Warblers wintering in California breed and how this might drive the variation in numbers recorded at migration stations from year to year would provide needed insight into the migration patterns of this warbler. 


\section{Chapter 5. Literature Cited}

Able, K. P. 1977. The orientation of passerine nocturnal migrants following offshore drift. Auk 94: 320-330.

Alerstram, T., and A. Lindstrom. 1990. Optimal bird migration: the relative importance of time, energy and safety. Pp. 331-351. In: E. Gwinner, editor. Bird Migration: the Physiology and Ecophysiology. SpringerVerlag, Berlin.

Ammon, E. M., and W. M. Gilbert. 1999. Wilson's Warbler (Wilsonia pusilla). Birds of North America 478:1-27.

Askins, R. A., J. F. Lynch, and R. Greenberg. 1990. Population declines in migratory birds in eastern North America. Current Ornithology $7: 1-57$.

Baker, R. R. 1978. The evolutionary ecology of animal migration. Holmes and Meier Publishers, New York, New York.

Bell, C. P. 1996. Seasonality and time allocation as causes of leap-frog migration in the yellow wagtail Motacilla flava. Journal of Avian Biology 27:334-342.

Bell, C. P. 1997. Leap-frog migration in the fox sparrow: Minimizing the cost of spring migration. Condor 99:470-477.

Bellrose F. C., and R. R. Graber. 1963. A radar study of the flight directions of nocturnal migrants. Proceedings XIII International Ornithological Congress 362-389.

Berthold, P. 1975. Migration: Control and metabolic physiology. Avian Biology 5:77-128.

Berthold, P. 1991. Genetic control of migratory behaviour in birds. Trends in Ecology and Evolution 6:254-257.

Berthold, P. 1996. Control of bird migration. Chapman and Hall, London.

Berthold, P. 1999. A comprehensive theory for the evolution, control and adaptability of avian migration. Ostrich 70:1-11.

Berthold, P., and A. J. Helbig. 1992. The genetics of bird migration: Stimulus, timing, and direction. Ibis 134:35-40.

Blem, C. R. 1990. Avian energy storage. Current Ornithology 7:59-113.
Carpenter, F. L., M. A. Hixon, R. W. Russell, D. C. Paton, and E. J. Temeles. 1993. Interference asymmetries among age-sex classes of rufous hummingbirds during migratory stopovers. Behavioral Ecology and Sociobiology 33:297304.

Chamberlain, C. P., J. D. Blum, R. T. Holmes, X. Feng, T. W. Sherry, and G. R. Graves. 1997. The use of isotope tracers for identifying populations of migratory birds. Oecologia 109:132-141.

Chase, M. K., N. Nur, and G. R. Geupel. 1997. Survival, productivity, and abundance in a Wilson's Warbler population. Auk 114:354-366.

Clegg, S. M., J. F. Kelly, M. Kimura, and T. B. Smith. 2003. Combining genetic markers and stable isotopes to reveal population connectivity and migration patterns in a Neotropical migrant, Wilson's warbler (Wilsonia pusilla). Molecular Ecology 12:819-830.

Connie, K. H., B. W. Anderson, R. D. Ohmart, and J.F. Drake. 1979. Responses of riparian species to agricultural habitat conversions. Pp. 248-262. In R. R. Johnson and F. F. Mcormick, technical editors. Strategies for protection and management of floodplain wetlands and other riparian ecosytems. U.S. Department of Agriculture, Forest Service General Technical Report WO-12.

Cooke, W. W. 1915. Bird Migration. US Department of Agriculture Bulletin no. 185. Washington, D.C.

Crawford, R. L., and H. M. Stevenson. 1984. Patterns of spring and fall migration in northwest Florida. Journal of Field Ornithology 55:196-203.

DeSante, D. F., and T. L. George. 1994. Population trends in the landbirds of western North America. Studies in Avian Biology 15:173-190.

Diehl, R. H., R. P. Larkin, and J. E. Black. 2003. Radar observations of bird migration over the Great Lakes. Auk 120:278-290.

Dobzhansky, T., and S. Wright. 1943. Genetics of natural populations X. Dispersion rates in Drosophila pseadoobscura. Genetics 28:304348. 
Emlen, S.T. 1975. Migration: Orientation and navigation. Avian Biology 5: 129-219.

Farquhar, G. D., J. R. Ehleringer, and K. T. Hubick. 1989. Carbon isotope discrimination and photosynthesis. Annual Review of Plant Physiology Plant Molecular Biology 40:503537.

Finch, D. M., and L. F. Ruggiero. 1993. Wildlife habitats and biological diversity in the Rocky Mountains and northern Great Plains. Natural Areas Journal 13:191-203.

Finch, D. M., and W. Yong. 2000. Landbird migration in riparian habitats of the middle Rio Grande: a case study. Studies in Avian Biology 20:88-98.

Fisher, R. A. 1930. The Genetical Theory of Natural Selection. Oxford University Press, London and New York.

Francis, C. M., and A. F. Cooke. 1986. Differential timing of spring migration in wood warblers (Parulinae). Auk 103:548-556

Gauthreaux, S. A., Jr. 1979. Priorities in Bird Migration Studies. Auk 96:813-815.

Gauthreaux, S. A., Jr. 1980. The influence of global climatological factors on the evolution of bird migratory pathways. Acta Congressus Internationalis Ornithologici 1:517-525.

Gauthreaux, S. A., Jr. 1982a. Age-dependent orientation in migratory birds. Pp. 68-74. In F. Papi and $\mathrm{H}$. Wallraff, editors. Avian Navigation. Springer-Verlag, Heidelberg.

Gauthreaux, S. A., Jr. 1982b. The ecology and evolution of avian migration systems. Avian Biology 6:93-168.

Gauthreaux, S. A., Jr. 1991. The flight behavior of migrating birds in changing wind fields: Radar and visual analyses. American Zoologist 31:187-204.

Gill, J. A., K. Norris, P. M. Potts, T. G. Gunnarsson, P. W. Atkinson, and W. J. Sutherland. 2001. The buffer effect and large-scale population regulation in migratory birds. Nature 412:436438.

Greenberg, R. 1980. Demographic aspects of longdistance migration. Pp. 493-504. In A. Keast and E. S. Morton, editors. Migrant birds in the Neotropics. Ecology, behavior, distribution and conservation. Smithsonian Institution Press, Washington, D.C.
Hagan, J. M., and D. W. Johnston. 1992. Ecology and conservation of neotropical migrant landbirds. Smithsonian Institution Press, Washington and London.

Helbig, A. J. 1996. Genetic basis, mode of inheritance and evolutionary changes of migratory directions in palearctic warblers (Aves: Sylviidae). Journal of Experimental Biology 199:49-55.

Helbig, A. J. 2003. Evolution of bird migration. Pp. 3-20. In P. Berthold, E. Gwinner, and E. Sonnenschein, editors. Avian Migration. Springer, London.

Hobson, K. A. 1999. Stable-carbon and nitrogen isotope ratios of songbird feathers grown in two terrestrial biomes: Implications for evaluating trophic relationships and breeding origins. Condor 101:799-805.

Hobson, K. A. 2003. Making migratory connections with stable isotopes. Pp. 380391. In P. Berthold, E. Gwinner, and E. Sonnenschein, editors. Avian Migration. Springer, London.

Hobson, K. A., and L.I. Wassenaar. 1997. Linking breeding and wintering grounds of neotropical migrant songbirds using stable hydrogen isotopic analysis of feathers. Oecologia 109:142-148.

Holmes, R. T., and T. W. Sherry. 2001. Thirtyyear bird population trends in an unfragmented temperate deciduous forest: Importance of habitat change. Auk 118:589-609.

Holmgren, N., and S. Lundberg. 1993. Despotic behaviour and the evolution of migration patterns in birds. Ornis Scandinavica 24:103109.

Hunter, W. C., R. D. Ohmart, and B. W. Anderson. 1988. Use of exotic saltcedar (Tamarix chinensis) by birds in arid riparian systems. Condor 90:113-123.

Hutto, R. L. 1985. Seasonal changes in the habitat distribution of transient insectivorous birds in southeastern Arizona: Competition mediated? Auk 102:120-132.

Hutto, R. L. 2000. On the importance of en route periods to the conservation of migratory landbirds. Studies in Avian Biology 20:109-114.

Ingraham, N. L. 1998. Isotopic variation in precipitation. Pp. 87-118. In C. Kendall and 
J. J. McDonnell, editors. Isotope Tracers in Catchment Hydrology. Elsevier Science B.V.

Johnson, R. R., L. T. Haight, and J. M. Simpson. 1977. Endangered species vs. endangered habitats: a concept. Pp. 68-79. In R. R. Johnson and D. A. Jones, editors. Importance, preservation, and management of riparian habitat. U.S. Forest Service General Technical Report RM-43.

Kelly, J. F., L. S. Delay, and D. M. Finch. 2002a. Density-dependent mass gain by Wilson's warblers during stopover. Auk 119:210-213.

Kelly, J. I., V. Atudorei, Z. I. Sharp, and D. I. Finch. 2002b. Insights into Wilson's Warbler migration from analyses of hydrogen stable-isotope ratios. Oecologia 130:216.

Ketterson, E. D., and V. J. Nolan. 1982. The role of migration and winter mortality in the life history of a temperate-zone migrant, the Dark-Eyed Junco, as determined from demographic analyses of winter populations. Auk 99:243-259.

Kimura, M., S. M. Clegg, , I. J. Lovette, K. R. Holder, D. J. Girman, B. Mila, P. Wade, and T. B. Smith. 2002. Phylogeographical approaches to assessing demographic connectivity between breeding and overwintering regions in a Nearctic-Neotropical warbler (Wilsonia pusilla ). Molecular Ecology 11:1605-1616.

Knopf, F. L., R. R. Johnson, T. Rich, F. B. Samson, and R. C. Szaro. 1988. Conservation of riparian ecosystems in the United States. Wilson Bulletin 100:272-284.

Knopf, F. L., and R. W. Cannon. 1982. Structural resilience of a willow riparian community to changes in grazing practices. Pp. 198-207. In J. M. Peek and P. D. Dalk, technical editors. Wildlife-livestock relationships symposium. Idaho Forestry, Wildlife, and Range Exp. Station., Moscow, Idaho.

Lack, D. 1954. The Natural Regulations of Animal Numbers. Oxford University Press, London and New York.

Lack, D. 1968. Bird migration and natural selection. Oikos 19:1-9.

Lindstrom, A. 1990. The role of predation risk in stopover habitat selection in migrating bramblings, Fringilla montifringilla. Behavioral Ecology 1:102-106.

Lovette, I. J., S. M. Clegg, and T. B. Smith. 2004. Limited utility of mtDNA markers for determining connectivity among breeding and overwintering locations in three Neotropical migrant birds. Conservation Biology 18:156-166.

Lundberg, S., and T. Alerstam. 1986. Bird migration patterns: Conditions for stable geographical population segregation. Journal of Theoretical Biology 123:403-414.

McCall, J. D., and R. F. Knox. 1979. Riparian habitat in channelization projects. Pp. 125128. In R. R. Johnson and F. F. Mcormick, technical editors. Strategies for protection and management of floodplain wetlands and other riparian ecosystems. U.S. Department of Agriculture, Forest Service General Technical Report WO-12.

Marra, P. P., K. A. Hobson, and R. T. Holmes. 1998. Linking winter and summer events in a migratory bird by using stable-carbon isotopes . Science 282:1884-1886.

Meehan, T. D., C. A. Lott, Z. D. Sharp, R. B. Smith, R. N. Rosenfield, A. C. Stewart, and R. K. Murphy. 2001. Using hydrogen isotope geochemistry to estimate the natal latitudes of immature Cooper's hawks migrating through the Florida Keys. Condor 103: 11-20.

Meehan, T. D., J. T. Tomasz Giermakowski, and P. M. Cryan. 2004. GIS-based model of stable hydrogen isotope ratios in North American precipitation for use in animal movement studies. Isotopes in Environmental and Health Studies 40:291-300.

Metcalfe, N. B., and R. W. Furness. 1984. Changing priorities: The effect of pre-migratory fattening on the trade-off between foraging and vigilance. Behavioral Ecology and Sociobiology 15:203-206.

Mila, B., D. J. Girman, M. Kimura, and T. B. Smith. 2000. Genetic evidence for the effect of a postglacial population expansion on the phylogeography of a North American songbird. Proceedings of the Royal Society of London 267:1033-1040

Moore, F. R. 1994. Resumption of feeding under risk of predation: Effect of migratory condition. Animal Behaviour 48:975-977

Moore, F. R., and D. A. Aborn. 2000. Mechanisms of en route habitat selections: How do migrants make habitat decisions during stopover? Studies in Avian Biology 20: 34-42 
Moore, F. R., S. A. Gauthreaux Jr., P. Kerlinger, and T. R. Simons. 1995. Habitat requirements during migration: important link in conservation. Pp. 121-144. In T. E. Martin and D. M. Finch, editors. Ecology and Management of Neotropical Migratory Birds: A Synthesis and Review of Critical Issues. Oxford University Press, New York, NY.

Moore, F. R., and T. R. Simons. 1992. Habitat suitability and stopover ecology of Neotropical landbird migrants. Pp. 345-355. In J. M. Hagan and D. W. Johnston, editors. Ecology and Conservation of Neotropical Migrant Landbirds. Smithsonian Institution Press, Washington and London.

Moore, F. R., and W. Yong. 1991. Evidence of food-based competition among passerine migrants during stopover. Behavioral Ecology and Sociobiology 28:85-90

Otahal, C.D. 1995. Sexual differences in Wilson's Warbler migration. Journal of Field Ornithology 66:60-69

Phillips, A. R. 1975. The migrations of Allen's and other hummingbirds. Condor 77:196205

Pitocchelli, J. 1995. MacGillivray's Warbler (Oporornis tolmiei). The Birds of North America 159:1-15

Pulido, F., and P. Berthold. 2003. Quantitative genetic analysis of migratory behaviour. Pp. 53-77. In P. Berthold, E. Gwinner, and E. Sonnenschein, editors. Avian Migration. Springer, London.

Pyle, P. 1997. Identification guide to North American birds Part I. Slate Creek Press, Bolinas, CA.

Rappole, J.H. 1995. The ecology of migrant birds. Smithsonian Institution Press, Washington and London.

Rappole, J. H., B. Helm, and M. A. Ramos. 2003. An integrative framework for understanding the origin and evolution of avian migration. Journal of Avian Biology 34:124-128

Rappole, J. H., and M. A. Ramos. 1994. Factors affecting migratory bird routes over the Gulf of Mexico. Bird Conservation International 4:251-262

Rich, T. D., C. J. Beardmore, H. Berlanga, P. J. Blancher, M. S. W. Bradstreet, G. S. Butcher,
D. W. Demarest, E. H. Dunn, W. C. Hunter, E. E. Inigo-Elias, J. A. Kennedy, A. M. Martell, A. O. Panjabi, D. N. Pashley, K. V. Rosenberg, C. M. Rustay, J. S. Wendt, and T. C. Will. 2004. Partners in Flight North American landbird conservation plan. Ithaca, NY, Cornell Lab of Ornithology.

Robbins, C. S., J. R. Sauer, R. S. Greenberg, and S. Droege. 1989. Population declines in North American birds that migrate to the neotropics. Proceedings of the National Academy of Sciences, USA 86: 7658-7662

Rubenstein, D. R., C. P. Chamberlain, R. T. Holmes, M. P. Ayres, J. R. Waldbauer, G. R. Graves, and N. C. Tuross. 2002. Linking breeding and wintering ranges of a migratory songbird using stable isotopes. Science 295:106-1065

Salomonsen, F. 1955. The evolutionary significance of bird-migration. Dan. Biol. Medd. 22:1-62

Sauer, J. R., J. E. Hiner, and J. Fallon. 2003. The North American Breeding Bird Survey, results and analysis 1996-2002. Version 2003.1. Laurel, MD, Patuxent Wildlife Research Center. Sherry, T. W., and R. T. Holmes. 1995. Summer versus winter limitation of populations: what are the issues and what is the evidence? Pp. 85120. In T. E. Martin and D. M. Finch, editors. Ecology and Management of Neotropical Migratory Birds: A Synthesis and Review of Critical Issues. Oxford University Press, New York, NY.

Sillett, T. S., and R. T. Holmes. 2002. Variation in survivorship of a migratory songbird throughout its annual cycle. Journal of Animal Ecology 71:296-308

Smith, R. B., T. D. Meehan, and B. O. Wolf. 2003. Assessing migration patterns of sharp-shinned hawks Accipiter striatus using stable-isotope and band encounter analysis. Journal of Avian Biology 34:387-392

Sprunt, A. 1975. Habitat management implications of migration. Pp. 81-86. Proceedings of Symposium of Management of Forest and Range Habitats for Non-game Birds. USDA Forest Service General Technical Report. WO-1. Stevens, L. E., B. T. Brown, J. M. Simpson, and R. R. Johnson. 1977. The importance of riparian habitat to migrating birds. Pp. 156-164. In R. R. 
Johnson and D. A. Jones, editors. Importance, preservation, and management of riparian habitat. U.S. Forest Service General Technical Report RM-43.

Wassenaar, L. I., and K. A. Hobson. 2001. A stable-isotope approach to delineate geographical catchment areas of avian migration monitoring stations in North America. Environmental Science and Technology 35:1845-1850

Wassenaar, L. I., and K. A. Hobson. 2003. Comparative equilibration and online technique for determination of nonexchangeable hydrogen of keratins for use in animal migration studies. Isotopes in Environmental and Health Studies 39:1-7

Wauer, R. H. 1977. Significance of Rio Grande riparian systems upon avifauna. Pp. 165-174. In R. R. Johnson and D. A. Jones, editors. Importance, preservation, and management of riparian habitat. U.S. Forest Service General Technical Report RM-43
Weber, T. P., B. J. Ens, and A. I. Houston. 1998. Optimal avian migration: a dynamic model of fuel stores and site use. Evolutionary Ecology 12:377-401

Webster, M. S., P. P. Marra, S. M. Haig, S. Bensch, and R. T. Holmes. 2002. Links between worlds: unraveling migratory connectivity. Trends in Ecology \& Evolution 17:76-83

Williams, J. M. 1996. Nashville Warbler (Vermicora ruficapilla). The Birds of North America 205:1-19

Woodrey, M. S. 2000. Age-dependent aspects of stopover biology of passerine migrants. Studies in Avian Biology 20:43-52.

Yong, W., D. M. Finch, F. R. Moore, and J. F. Kelly. 1998. Stopover ecology and habitat use of migratory Wilson's warblers. Auk 115:829-842 
